\title{
A new early Visean coral assemblage from Azrou-Khenifra Basin, central Morocco and palaeobiogeographic implications
}

\author{
Sergio Rodríguez ${ }^{1,2^{*}}$ (D) lan D. Somerville ${ }^{3}$, Pedro Cózar ${ }^{2}$, Javier Sanz-López ${ }^{4}$, Ismael Coronado ${ }^{5}$, Felipe González ${ }^{6}$,
} Ismail Said ${ }^{1}$ and Mohamed El Houicha ${ }^{7}$

\begin{abstract}
A new early Visean coral assemblage has been recorded from turbidite facies in the southern part of the AzrouKhenifra Basin, northwest of Khenifra, central Morocco. The newly discovered Ba Moussa West (BMW) coral fauna includes Siphonophyllia khenifrense sp. nov., Sychnoelasma urbanowitschi, Cravenia lamellata, Cravenia tela, Cravenia rhytoides, Turnacipora megastoma and Pleurosiphonella crustosa. The early Visean age of the coral assemblage is supported by foraminiferal and conodont data, with the recognition of the basal Visean MFZ9 Zone. This confirms that the first transgression in the Azrou-Khenifra Basin was during the earliest Visean. The allochthonous coral assemblage was recovered from coarse-grained proximal limestone debris flow and turbidite beds within a faultbounded unit, lying to the west of a thrust syncline containing upper Visean limestones. No evidence exists of the former early Visean shallow-water platform from which the corals were derived. All other in situ platform carbonate rocks around the southern margin of the Azrou-Khenifra Basin are probably of late Visean (Asbian-Brigantian) age. The early Visean Ba Moussa West coral fauna can be compared with that at Tafilalt in eastern Morocco, as well as in other Saharian basins of Algeria. Many of the genera and species in the Ba Moussa West assemblage are identical to those in NW Europe, with which it must have had marine connections. The new rugose species described, Siphonophyllia khenifrense, is probably endemic to North Africa. Its ecological niche in NW Europe was occupied by S. cylindrica or S. aff. garwoodi.
\end{abstract}

Keywords: Mississippian, Visean, Corals, Foraminifers, Conodonts, Palaeobiogeography, Morocco

\section{Introduction}

Mississippian rocks are common in the Moroccan Meseta. They have been studied and described by French geologists since the beginning of the twentieth century (Lecointre 1926; Termier 1936; Termier and Termier 1950; Gigout 1951, etc.). The Mississippian stratigraphic successions are clearly different in the western and in the eastern parts of the Meseta. The stratigraphy in both areas, as well as in other regions from Morocco, has been summarized by Beauchamp and Izart (1987), Hoepffner et al. (2005) and Michard et al. (2010). The

\footnotetext{
* Correspondence: sergrodr@ucm.es

${ }^{1}$ GEODESPAL, Universidad Complutense de Madrid, c/José Antonio Novais.

12, 28040 Madrid, Spain

${ }^{2}$ Instituto de Geociencias (CSIC, UCM), c/ José Antonio Novais 12, 28040

Madrid, Spain

Full list of author information is available at the end of the article
}

succession was considered quite continuous from the Devonian to the Serpukhovian (Michard et al. 2010). However, sedimentation in the eastern part of the central Meseta (Azrou-Khenifra Basin) is more complicated. It took place in both a shallow-water carbonate platform and a deeper water flysch basin, within a tectonically active setting, involving movements of blocks, and transgressions and regressions that produced some gaps and unconformities. Sedimentation during the Tournaisian, early and mid Visean in the basin is regarded as being absent by some authors (Huvelin 1969; Beauchamp and Izart 1987), whereas continuous or sporadic sedimentation during that time interval is suggested by others (Bouabdelli 1989; Huvelin and Mamet 1997; Michard et al. 2010).

The purpose of this paper is to report the recent discovery of a relatively rich Mississippian (early Visean) 
coral fauna in the southern part of the Azrou-Khenifra Basin, to describe the corals in detail and their host limestone rocks, as well as to comment on their comparison and affinity with other coeval coral assemblages in North Africa, Europe and SW Asia. The microfossil content was also studied to enhance the biostratigraphic discussion and significance of the coral fauna.

\section{Geological setting}

The beginning of Carboniferous sedimentation in the Khenifra region, which lies in the southern part of the Azrou-Khenifra Basin and contains the largest Mississippian outcrops in the eastern central Meseta, is usually considered to occur within the widely known late Visean transgression (Huvelin 1969; Chanton-Güvenç et al. 1971; Semenoff-Tian-Chansky 1985; Beauchamp and Izart 1987; Michard et al. 2010; Aretz and Herbig 2010; Rodríguez et al. 2012; Somerville et al. 2012; Said et al. 2013). However, Huvelin and Mamet (1997) cited two early Visean transgressions. The first one is imprecisely located as "to the north of Ba Moussa (point 1)". The second one was equated with the base of V2b (= Cf5 Zone of Conil et al. 1990; Livian or Holkerian) of mid Visean age.

In the southwestern margin of the Azrou-Khenifra Basin at Sidi Lamine and Tabainout (Fig. 1b), a thick shallow-water carbonate succession with basal Mississippian conglomerate and sandy limestone can be seen to rest unconformably on older (Ordovician) tilted siltstones and sandstones (Aretz and Herbig 2010; Somerville et al. 2012; Said et al. 2013). A similar relationship is seen at the southeastern margin of the basin at Tiouinine (Fig. 1b) where shallow water sandy limestones rest unconformably on red Ordovician sandstones (Rodríguez et al. 2012).

The eastern part of the Azrou-Khenifra Basin, northwest of Khenifra, is a region of mostly deep-water rythmic mudstones. However, recent field investigations at Ba Moussa West, northwest of a nappe folded as a N-Strending syncline, and approximately $3 \mathrm{~km}$ northwest of Khenifra city margins (Figs. 1 and 2a), have discovered two pale gray weathering limestone units within a thick dark gray siltstone and shale rhythmic succession. These limestones contain abundant corals that form the focus of this paper. The limestone units form two distinct parallel ridges, some $50 \mathrm{~m}$ apart, and traceable laterally for over $200 \mathrm{~m}$ (Fig. 1c). They form prominent features on the landscape, compared to the subdued topography of the more easily eroded mudstones which encase the limestones (Fig. 2a). The beds dip steeply to the east $\left(70^{\circ}\right)$ and in places can be vertical (Fig. 2 a). The two ridges expose respectively, $4.90 \mathrm{~m}$ and $4.10 \mathrm{~m}$ thicknesses of well-bedded limestones (with beds ranging typically from 10 to $40 \mathrm{~cm}$ thick) with thin dark gray shale interbeds.
The limestones are variable in composition and texture, comprising coarse-grained, bioclastic and lithoclastic calcirudites, rich in crinoids, thick-shelled brachiopods and relatively abundant corals. The limestone beds consist of numerous sedimentary events. Some have sharp, erosive bases and show grading with laminated tops. Large angular lithoclasts of sandstone and siltstone (up to $20 \mathrm{~cm}$ in diameter) occur in some beds (Fig. $2 \mathrm{~b}-\mathrm{d}$ ). Other limestones are buff weathered, fine-grained, laminated calcarenites. Under the petrological microscope two microfacies are differentiated. The first microfacies, which is less common, is a laminated crinoidal wackestone-packstone containing small fragments of crinoidal plates, corals and bryozoans. The second one, which is dominant, is a polymictic rudstone with fragmented corals, crinoids, bryozoans, brachiopods, trilobites, gastropods, bivalves, foraminifers and angular to subangular grains of quartzite (Fig. 2b) sandstone and siltstone (Fig. 2e, f). The disposition of siliciclastic clasts and bioclasts is random in some beds (Fig. 2e), suggesting rapid sedimentation, but in some beds, most clasts are disposed mainly parallel to the stratification (Fig. 2c). The fragmentation of bioclasts is also variable.

The limestones can be regarded as proximal debris flow and multistorey high-density turbidite bodies, with numerous event beds, deposited in a prevailing succession of distal turbidite beds. Thus, the coral assemblage is allochthonous and may have been transported far from its original depositional shelf setting.

\section{Methodology}

The two limestone horizons (BMW1 and BMW2) were sampled and corals were collected. Samples from BMW1 contain almost entire brachiopods and corals (Fig. 2d), whereas in BMW2 most bioclasts are completely broken and very few coral specimens are identifiable at generic or specific level. The coral assemblage is relatively rich, but their diversity is quite low (5 genera and 7 species). The assemblage comprises solitary rugose corals and tabulate colonies. Many corals are well preserved and nearly complete, missing only the apexes and showing sometimes compressed calices when they show few skeletal elements and are filled with muddy sediment. However, others are completely fragmented or crushed or have lost much of their dissepimentaria. Fifty specimens were collected, of which 38 have been definitively identified.

Thin sections of samples were studied to describe the microfossil content. Owing to the brecciated character of many beds, including boulders of large size, only the fine-grained limestones yield foraminifers. Assemblages are relatively abundant in those fine-grained limestones, although specimens are commonly crushed, and diversity is limited to a few genera. Assemblages from BMW1 are slightly richer than BMW2, although this may be the result of more intense sampling and sectioning. 


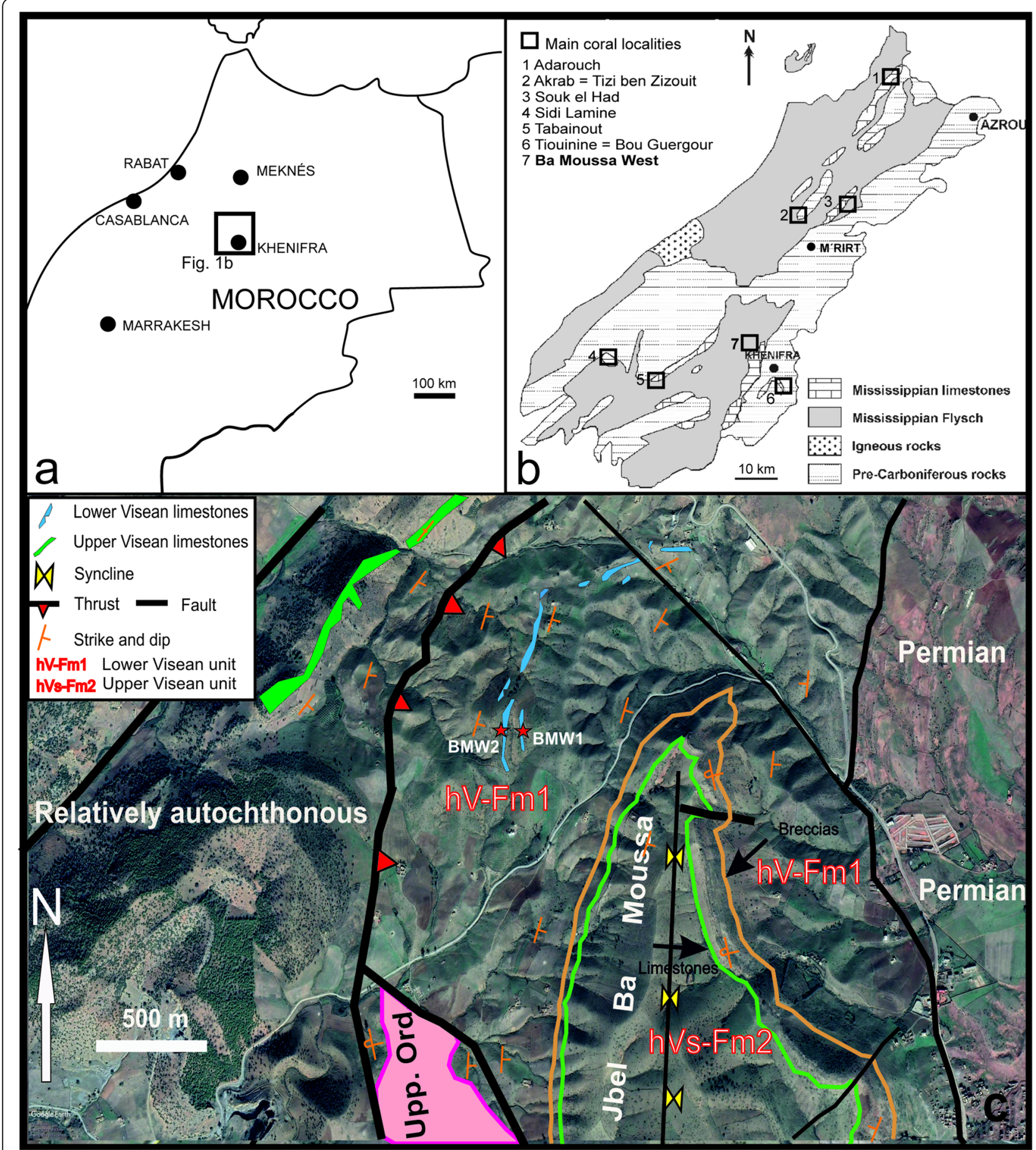

Fig. 1 a Location of Khenifra in central Morocco; b Geological map of Azrou-Khenifra Basin with Ba Moussa West coral fauna locality and other coral localities mentioned in the text; c Simplified geological sketch map of Ba Moussa West area and the location of the studied limestone horizons BMW1 and BMW2. hV-Fm1 = Lower Visean; hV-Fm2 = Upper Visean

A large sample from limestone BMW1 (3.8 kg weight) was etched with $8 \%-10 \%$ buffered formic acid solution, following the standard technique to avoid damaging. The low abundance of conodont elements includes one complete P1 element and six broken elements with upper surface damaged and a few with surface dissolution, which could be in relation to significant transport and resedimentation of elements (Fig. 3a-e). The colour of conodonts shows values of 4.5 to 5 for the alteration index (CAI). Reworking of conodonts may be causing a higher CAI value, but small recrystallized apatite 

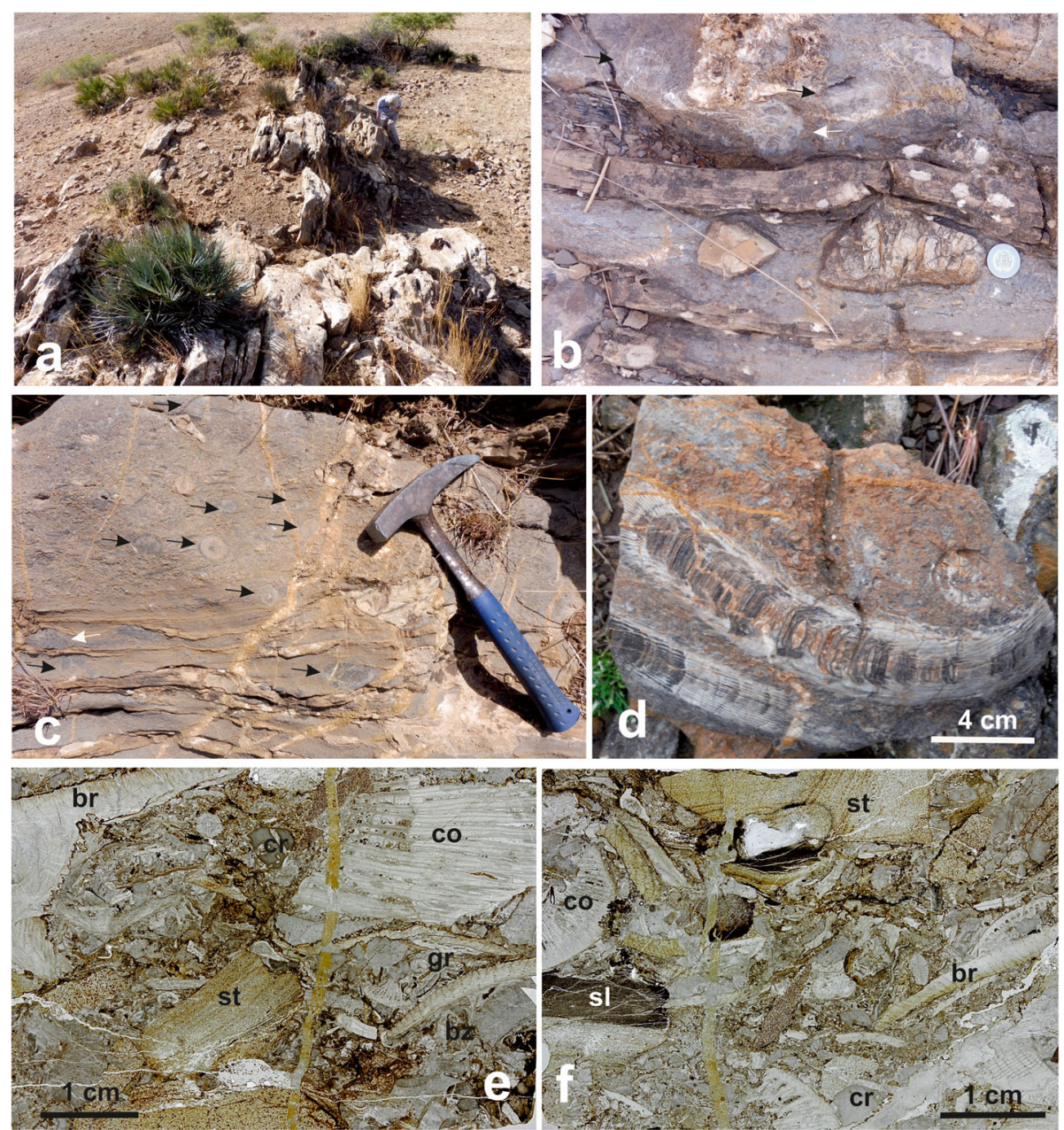

Fig. 2 a View looking south of limestone ridge (BMW1) C. $5 \mathrm{~m}$ thick showing steeply dipping beds overlain and underlain by softer shales; $\mathbf{b}$ Limestone bed with large angular quartzite and sandstone lithoclasts (beside coin) succeeded by thin laminated sandy limestone and black shales, in turn overlain by bioclastic limestone rich in corals (solitary rugose coral Siphonophyllia (black arrows) and cerioid tabulate coral Turnacipora (white arrow)) (coin diameter $=2.5 \mathrm{~cm}$ ); c Close-up view of richly bioclastic limestone bed with sharp base, showing abundant transverse sections of Siphonophyllia and Sychnoelasma (black arrows) (hammer length $=40 \mathrm{~cm}$ ); d Coarse-grained crinoidal limestone with longitudinal and transverse sections of Siphonophyllia khenifrense; e Thin section of rudstone at BMW1 showing bioclasts and lithoclasts. br= brachiopod, bz= bryozoan, $\mathrm{co}=$ coral, $\mathrm{cr}=$ crinoid, $\mathrm{gr}=$ gastropod, $\mathrm{st}=$ sandstone; $\mathbf{f}$ Thin section of rudstone at BMW2 showing bioclasts and lithoclasts. $\mathrm{br}=$ brachiopod, $\mathrm{co}=\mathrm{coral}, \mathrm{cr}=$ crinoid, $\mathrm{sl}=$ siltstone, $\mathrm{st}=$ sandstone

surface is observed in conodonts (Fig. 3b). Some specimens preserve a smooth surface, but etched surfaces with pits are often discerned (Fig. 3f, h). It suggests short heating on proximity to an igneous intrusion.

The allochthonous shales embedding the limestone horizons were sampled for palynomorphs. A total of 12 shale samples were crushed and dissolved following the classical extraction techniques described by Wood et al. (1996). After complete removal of carbonate and silicate minerals, the organic remains were oxidized with Fuming Schulze solution and mounted in slides for microscope analysis. Palynomorphs recovered from shales are dominated by phytoclasts and, in minor proportions, by spores, whereas organic-walled marine microphytoplankton and amorphous organic matter are virtually absent. The reduced number of spores and their irregular state of preservation precluded further taxonomic identification. The large proportion of equidimensional to lath-shaped phytoclasts and the absence of marine components may be explained by the intense reworking and effective dilution associated to low-density turbidity currents (Tyson 1993, 1995). The brownish-black to black colour of spores and phytoclasts points to a thermal alteration index (TAI) close to 5 , which essentially agrees with the CAI values observed for conodonts from the limestone sample. 


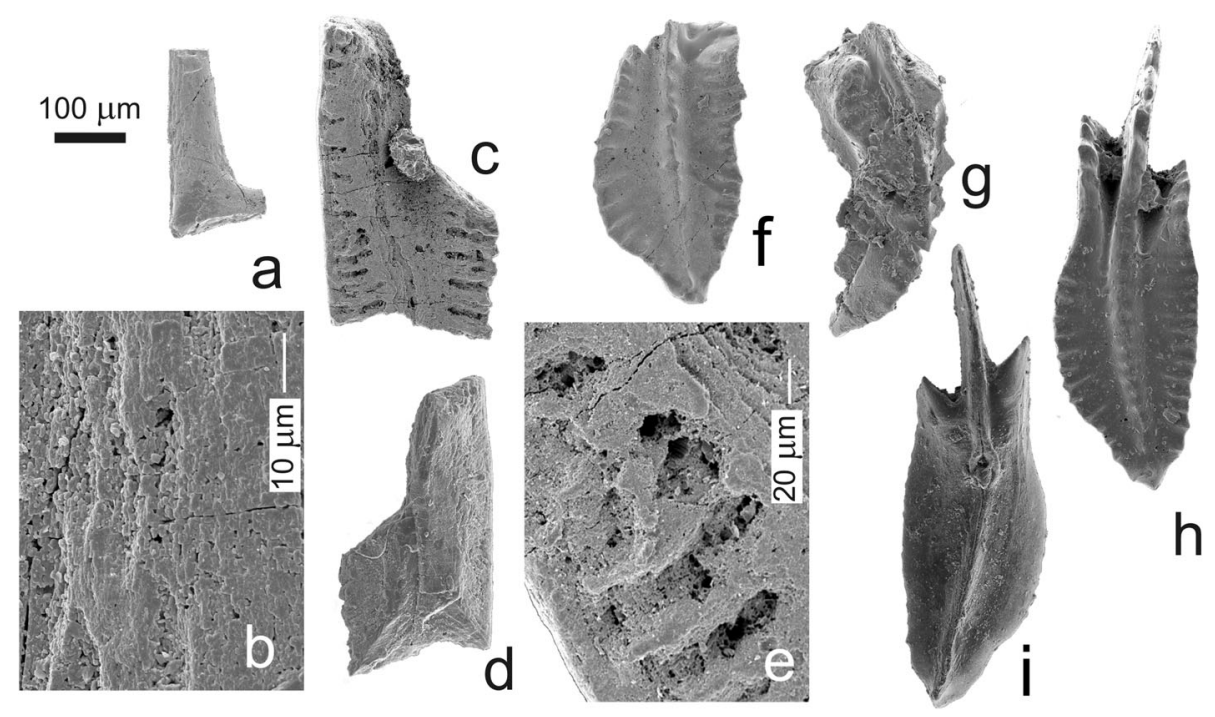

Fig. 3 Conodonts from samples of BMW1. a-b Fragment of element of Kladognathus sp., DGO 15624, and detail of the face where breakage shows a lamellar inner structure and small apatite crystal 2-3 $\mathrm{mm}$ in size interpreted as recystallized and, later, slight dissolution; c-e Aboral and oral views of Mestognathus cf. beckmanni, DGO 15625, and detail of the margin of the platform with a strong dissolution located on the ornamentation of ridges and carina causing the inversion of surface relief; $\mathbf{f}$ Oral view of Polygnathus lobatus with pits due to dissolution of the conodont surface, DGO 15622; g Gnathodus pseudosemiglaber, DGO 15623; h-i Oral and aboral views of Polygnathus inornatus, DGO 15621. Conodonts are stored in the Museum of Geology of the Department of Geology at the University of Oviedo, Spain (abbreviated DGO)

\section{The coral assemblage and its biostratigraphic significance}

The coral assemblage from Ba Moussa West contains Siphonophyllia khenifrense sp. nov., with other solitary rugose corals, such as Sychnoelasma urbanowitschi (Stuckenberg 1895), Cravenia lamellata Howell 1938, C. tela Hudson 1928, C. rhytoides Hudson 1928. Colonial tabulate corals recorded include Turnacipora megastoma (Phillips 1836) and Pleurosiphonella crustosa Tchudinova 1970. The most abundant specimens collected belong to the genus Siphonophyllia (20) and Turnacipora (7). Most other species are represented only by three specimens or less.

The assemblage is similar to that described from lower Visean (Arundian) Moel Hiraddug Formation in North Wales, UK (Somerville et al. 1986). In both regions the large siphonophylliid corals represent the dominant component in dark gray bioclastic limestone and shale lithofacies, in which colonial rugose corals are absent. However, the Ba Moussa succession has a lower diversity coral assemblage and the specimens are not as well preserved. This may be explained by the sedimentological setting at Ba Moussa, with the corals occurring in graded limestone beds containing large exotic clasts, interpreted as debris flow and proximal turbidite deposits.

The stratigraphic range of Sychnoelasma urbanowitschi, and the three species of Cravenia (C. lamellata, C. tela, and C. rhytoides) is very restricted, typically diagnostic of the early Visean throughout Western Europe (Hudson 1928; Howell 1938; Poty 1981, 1983; Denayer et al. 2011). Turnacipora megastoma occurs also, typically in the early Visean (Lafuste and Plusquellec 1985; Somerville et al. 1986).

The Ba Moussa West assemblage has similarities with Tafilalt in Eastern Morocco, where a richer early Visean solitary rugose assemblage is recorded (see Denayer 2015), including Cravenia, Siphonophyllia and Sychnoelasma, but where colonial rugose genera are also absent. Similar assemblages containing dominant cyathopsids plus Sychnoelasma, Pleurosiphonella and micheliniids have been reported in Canada and United States (Bamber and Sando 1985; Sando and Bamber 1985), and in Mid-Asia (Tchudinova 1986; Leleshus 1991).

The Ba Moussa limestone beds are clearly older than other Mississippian sections in the Khenifra area, as confirmed by the associated foraminifers and conodonts. Coral assemblages from Tabainout and Sidi Lamine, $20 \mathrm{~km}$ and $30 \mathrm{~km}$ respectively, further west of Ba Moussa West, at the western margin of the Azrou-Khenifra Basin, contain fasciculate and massive colonial rugose coral genera (Siphonodendron and Lithostrotion) of late Visean (Asbian) age (Aretz and Herbig 2010; Rodríguez et al. 2012; Somerville et al. 2012; Said et al. 2013). Both sections have basal transgressive deposits with in situ shallow-water limestones containing ooids and calcareous algae (Somerville et al. 2012; Said et al. 2013). At Tiouinine, 8 $\mathrm{km} \mathrm{SE}$ of Khenifra on the eastern margin of the basin, very rich and diverse late Visean (Brigantian) coral assemblages form a reefal tract (Rodríguez et al. 2012). The early Visean age of the Ba Moussa West limestone correlates with the early Visean age of the transgressive point 1 of Huvelin and Mamet (1997) located "to the north of Ba Moussa" (Table 1). 
Table 1 Foraminifer, conodont and coral zonations for Tournaisian and Visean in Western Palaeotethys related to the transgressions (TR1 to TR4) identified in the Azrou-Khenifra Basin by Huvelin and Mamet (1997). Note that TR1 is moved down into MFZ9 in accordance with results in this work

\begin{tabular}{|c|c|c|c|c|c|c|c|c|c|}
\hline & \multicolumn{2}{|c|}{ Foraminifers } & Conodonts & \multicolumn{3}{|c|}{ Corals } & \multirow{2}{*}{$\begin{array}{c}\text { 3rd sequence } \\
\text { Poty et al. } 2006 \\
\end{array}$} & \multirow{2}{*}{$\begin{array}{c}\text { Azrou-Khenifra Basin } \\
\text { Huvelin and Mamet } 1997\end{array}$} \\
\hline & & Poty et al. 2006 & Mamet 1974 & Poty et al. 2006 & \multicolumn{2}{|c|}{ Poty et al. 2006} & Mitchell 1989 & & \\
\hline \multirow{17}{*}{ 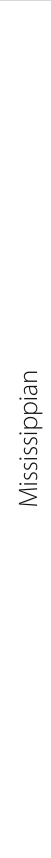 } & & MFZ15 & $16 \mathrm{~s}$ & \multirow{3}{*}{ bilineatus bilineatus } & \multicolumn{2}{|c|}{$\mathrm{RC} 8$} & $\mathrm{H}-\mathrm{K}$ & 10 & \\
\hline & \multirow{7}{*}{ 怘 } & ME714 & $16 \mathrm{i}$ & & \multirow{2}{*}{ RC7 } & $\beta$ & G & \multirow{2}{*}{9} & \\
\hline & & MFZ13 & 15 & & & $a$ & $\mathrm{~F}$ & & \multirow{2}{*}{ TR4 } \\
\hline & & \multirow{2}{*}{ MFZ12 } & 14 & \multirow{5}{*}{$\begin{array}{l}\text { transatlanticus, } \\
\text { cracoviensis, } \\
\text { homopunctatus }\end{array}$} & \multirow{2}{*}{\multicolumn{2}{|c|}{$\mathrm{RC} 6$}} & \multirow[b]{2}{*}{$E$} & \multirow[t]{2}{*}{8} & \\
\hline & & & 13 & & & & & & TR3 \\
\hline & & MFZ11 & 12 & & \multicolumn{2}{|c|}{ RC5 } & $\bar{D}$ & \multirow{2}{*}{6} & TR2 \\
\hline & & MFZ10 & 11 & & \multirow{4}{*}{ RC4 } & \multirow{2}{*}{$\beta 2$} & $B-C$ & & \\
\hline & & MFZ9 & 10 & & & & A & 5 & TR1 \\
\hline & \multirow{9}{*}{ 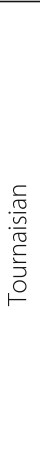 } & MFZ8 & \multirow{3}{*}{9} & praebeckmanni & & 01 & cylindrica & & \\
\hline & & MFZ7 & & bischoffi & & & & 4 & \\
\hline & & MFZ6 & & latus & \multirow{3}{*}{$\mathrm{RC3}$} & Y & & & \\
\hline & & \multirow{2}{*}{ MFZ5 } & \multirow{2}{*}{8} & hourkerti & & $\beta$ & & \multirow{3}{*}{3} & \\
\hline & & & & oonckuerd & & a & & & \\
\hline & & MFZ4 & & Gnathodus & & & & & \\
\hline & & MFZ3 & 7 & & & & & & \\
\hline & & MFZ2 & & obsoleta & & Y & & 2 & \\
\hline & & MFZ1 & & duplicata, cooperi & & & & 1 & \\
\hline
\end{tabular}

\section{Microfossils and age of limestones}

\subsection{Foraminifers and Algospongia}

The assemblage in samples from BMW1 contains the foraminifers Earlandia vulgaris, E. elegans, Endothyra spp., E. similis, Endolaxina sp., Endothyranopsis (Eosinopsis) sp., Eosparastaffella sp., E. concinna, E. evoluta, E. interiecta, E. macdermoti, E. aff. macdermoti, E. ovalis, E. simplex, E. tumida subsp. 1, E. vdovenkoae, Eotextularia diversa, Granuliferella sp., Globoendothyra sp., Lapparentidiscus sp.,? Lituotubella sp., Mediocris mediocris, M. ovalis, M. aff. ovalis, Omphalotis sp., Pseudoplanoendothyra sp., Septabrunsiina sp., Septaglomospiranella sp., Spinobrunsiina sp., Spinolaxina sp., Tetrataxis sp. and Urbanella (Brenckleites) fragilis. The Algospongia recorded are very common Kamaena delicata and Palaeoberesella lahoseni, as well as Stacheoides spissa and Exvotarisella sp. (Fig. 4).

The assemblage is characterized by a high diversity in Eoparastaffella species, and in particular, the first species with pointed periphery in the last whorl, E. tumida subsp. 1 and $E$. ex gr. simplex. Although the marker for the base of the MFZ9 of Poty et al. (2006), as well as the marker for the base of the Visean (Devuyst et al. 2003), E. tumida subsp. 1 is derived from $E$. simplex from the basal levels of the MFZ9 (Devuyst and Kalvoda 2007), and thus, the assemblages can be attributed to the base of the Visean. It is noteworthy for the occurrence of $E$. concinna and E. evoluta, also derived from E. simplex in more advances stages of the MFZ9.

The foraminiferal assemblage recorded in BMW2 is composed of Earlandia minor, E. vulgaris, Endothyra spp., E. ex gr. bowmani, E. prisca, E. similis, Eotextularia diversa, "Glomospira" sp., Eoparastaffella sp., E. concinna, E. interiecta, E. macdermoti, E. simplex, E. tumida subsp. 1, E. vdovenkoae, Mediocris mediocris, Latiendothyranopsis sp., Omphalotis sp., Plectogyranopsis sp., and Pseudoplanoendothyra sp. This assemblage also contains the pointed and slender Eoparastaffella, including E. concinna, which is a more evolved form than the ancestral stock of pointed Eoparastaffella. In consequence, the assemblage is also assigned to an advanced stage in the MFZ9. The Algospongia recorded in those levels contain Palaeoberesella lahoseni, Kamaena delicata, Issinella sp., and Exvotarisella sp. (Fig. 4).

\subsection{Conodonts}

The conodont fauna studied in samples from BMW1 includes Polygnathus inornatus Branson and Mehl 1934, P. lobatus Branson and Mehl 1938 (that is usually related with the first species), and a fragment of Polygnathus sp. (Fig. 3f, h-i). These taxa were usually described in the early to mid Tournaisian Siphonodella-Polygnathus inornatus Assemblage Zone of Rhodes et al. (1969) in the 

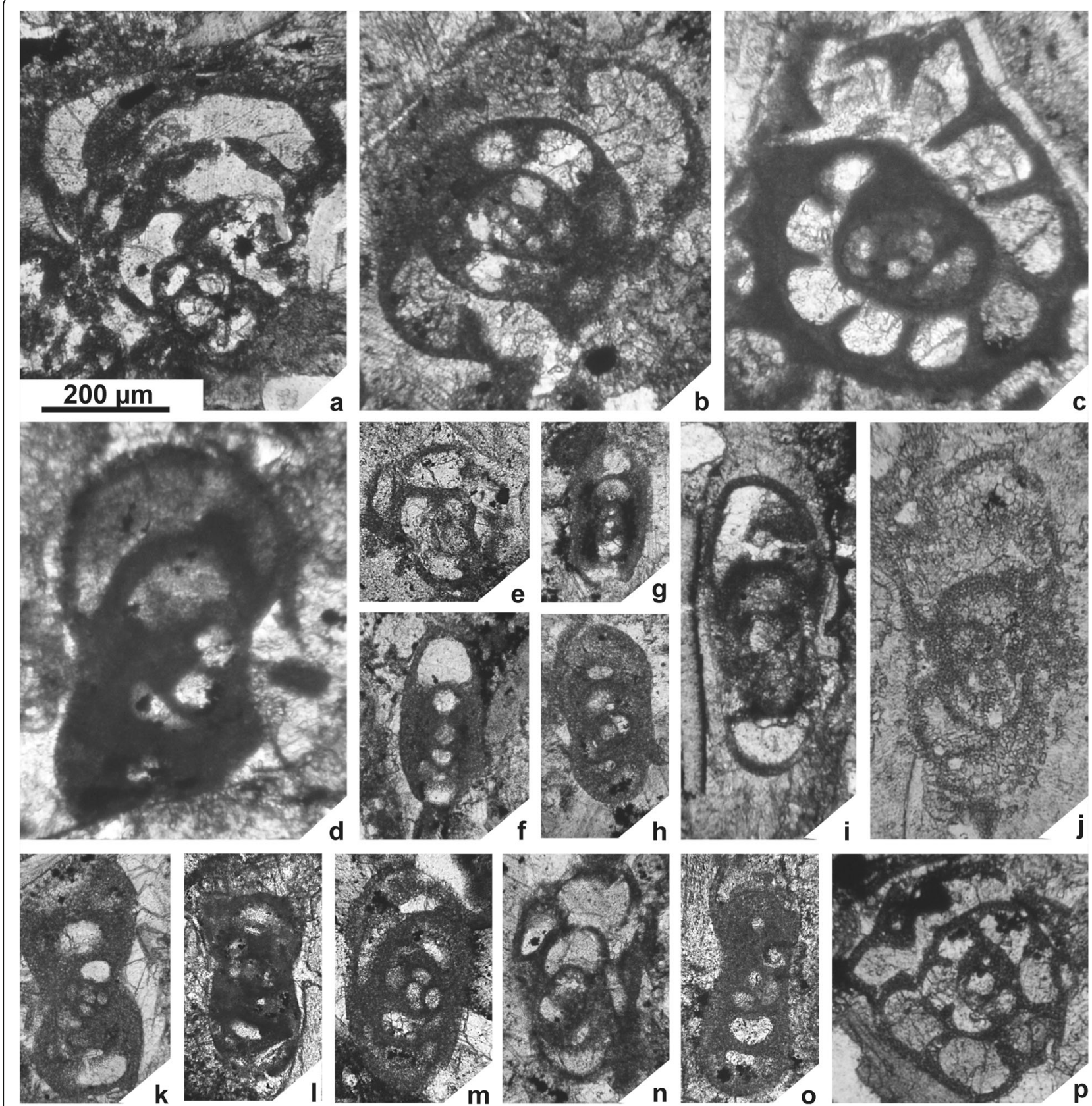

Fig. 4 a Eotextularia diversa, BMW1, Pc4367; b Latiendothyranopsis sp., BMW2; c Omphalotis sp., BMW1, Pc4364; d Eoparastaffella tumida, BMW1, Pc4364. e Granuliferella sp., BMW1, Pc4364; f Mediocris aff. Ovalis, BMW1, Pc4366; g Eoparastaffella simplex, BMW1, Pc4366; h Eoparastaffella ex gr. simplex (E. tumida subsp. 1), BMW1, Pc4367; i Eoparastaffella aff. Concinna, BMW1, Pc4365; j Eoparastaffella evoluta, BMW2; k Eoparastaffella vdovenkoae, BMW1, Pc4366; I Eoparastaffella macdermoti, BMW1, Pc4364; m Eoparastaffella ovalis, BMW1, Pc4367; n Endolaxina sp., BMW1, Pc4367; o Pseudoplanoendothyra sp., BMW1, Pc4364; p Endothyranopsis (Eosynopsis) sp., BMW1, Pc4364. Scale bar same for all figures

British Isles. However, Stewart (in Varker and Sevastopulo 1985 ) indicated that $P$. inornatus ranged up to the upper Tournaisian Gnathodus typicus Conodont Zone in Cornwall (UK). Polygnathus inornatus have been reported in the upper Tournaisian Scaliognathus anchoralis Zone of the Moravia-Silesia and the Dinant-Namur basins (Belka 1985; Belka and Groessens 1986), and in the earliest
Visean, just at the first occurrence of Pseudognathodus homopunctatus (Ziegler 1960) in the Belgian area. A late Tournaisian to early Visean age is supported by the occurrences of one P1 element of Gnathodus pseudosemiglaber Thompson and Fellows 1970, one P1 fragment of Mestognathus sp. and one P2 element probably corresponding to Kladognathus sp. (Fig. 3a, c-d, g). The fragment of 
Mestognathus sp. shows dissolution of the carina and ornamentation of the platform, and the blade and the dorsal part of the platform are broken. The parapet area is close to that described in M. praebeckmanni Sandberg, Johnston, Orchard and von Bitter 1986. The secondary keel seems to be formed with a basal groove (Fig. 3d), as in Mestognathus beckmanni Bischoff 1958, but the specimen is broken. The first occurrence of Mestognathus beckmanni was indicated just below the lower boundary of the Visean Stage at the GSSP in the Pengchong section, South China and in a few localities of Western Europe, although it is often recorded in Visean beds (Groessens 1975; von Bitter et al. 1986; Devuyst et al. 2003; Somerville 2008). The early Visean Ps. homopunctatus species is lacking in the studied sample.

\section{Systematic palaeontology}

The terminology used for the description is that proposed by Hill (1981) with some observations of Poty (1981). The microstructural description is based on the terminology of Semenoff-Tian-Chansky (1974) and Rodríguez (1984). All specimens are stored in the Area de Paleontología, Universidad Complutense de Madrid.

Phylum Coelenterata Frey and Leuckart 1847

Class Anthozoa Ehrenberg 1834

Subclass Rugosa Milne-Edwards and Haime 1850

Order Stauriida Verrill 1865

Suborder Caniniina Wang 1950

Family Cyathopsidae Dybowski 1873

Genus Siphonophyllia Scouler in McCoy 1844

Type species: Siphonophyllia cylindrica Scouler in McCoy 1844, p. 187, pl. 27, Fig. 5, Lower Carboniferous, Ardsallagh, Drumquin, Ireland.

Siphonophyllia khenifrense Rodríguez, Said and Somerville sp. nov. (Figs. 5 and 6 ).
Derivatio nominis: The name of the species refers to the town of Khenifra within the Azrou-Khenifra Basin in Morocco.

Holotype: Specimen DPM BMW1-1; other specimens collected in the same beds are regarded as paratypes.

Type locality, horizon and age: Ba Moussa West, 3 km W of Khenifra, Azrou-Khenifra Basin, north central Morocco, early Visean.

Material: 17 specimens (DPM BMW1-1, 2, 3A, 5, 6, 7A, 8, 9, 10, 11, 20A, 20B, 21, BMW2-1, 2, 3, 4B), 29 transverse sections, 15 longitudinal sections.

Diagnosis: Siphonophyllia having $17-31 \mathrm{~mm}$ tabularium diameter and 42-61 major septa. Shorter cardinal septum in cardinal fossula. Strong thickening of major septa in tabularium. Narrow dissepimentarium, 4-5 rows of regular interseptal dissepiments with occasional lonsdaleoid type in the periphery. Microstructure of wall is lamellar. That of septa is granulofibrous in the mesoplasm, and lamellar in the stereoplasm.

Description. (External characteristics): Cylindrical corallites between $20 \mathrm{~mm}$ and $40 \mathrm{~mm}$ in alar diameter and recorded fragments are up to $20 \mathrm{~cm}$ long, often without calice. The dissepimentarium is often abraded. The outer wall is thin.

(Internal characteristics): The tabularium diameter varies from $17 \mathrm{~mm}$ in immature stage to $31 \mathrm{~mm}$ in adult stage. The tabularium is wide, $3 / 5$ to $>4 / 5$ corallite diameter; the variation in tabularium width is a function of the age of the specimen (immature vs mature corallite) and variation in the width of the dissepimentarium, which although generally narrow, can also be variably preserved. The number of major septa ranges commonly between 42 and 61, but up to 68 may be present (Fig. 5a). The septa are long, almost reaching the axis in immature stage but withdrawn from the center in mature adult stage (Fig. 6b, d, g, h). They are straight to slightly flexuous in the tabularium, thinning axially and straight to sinuous in the dissepimentarium (Fig. 6a, b). Major septa are

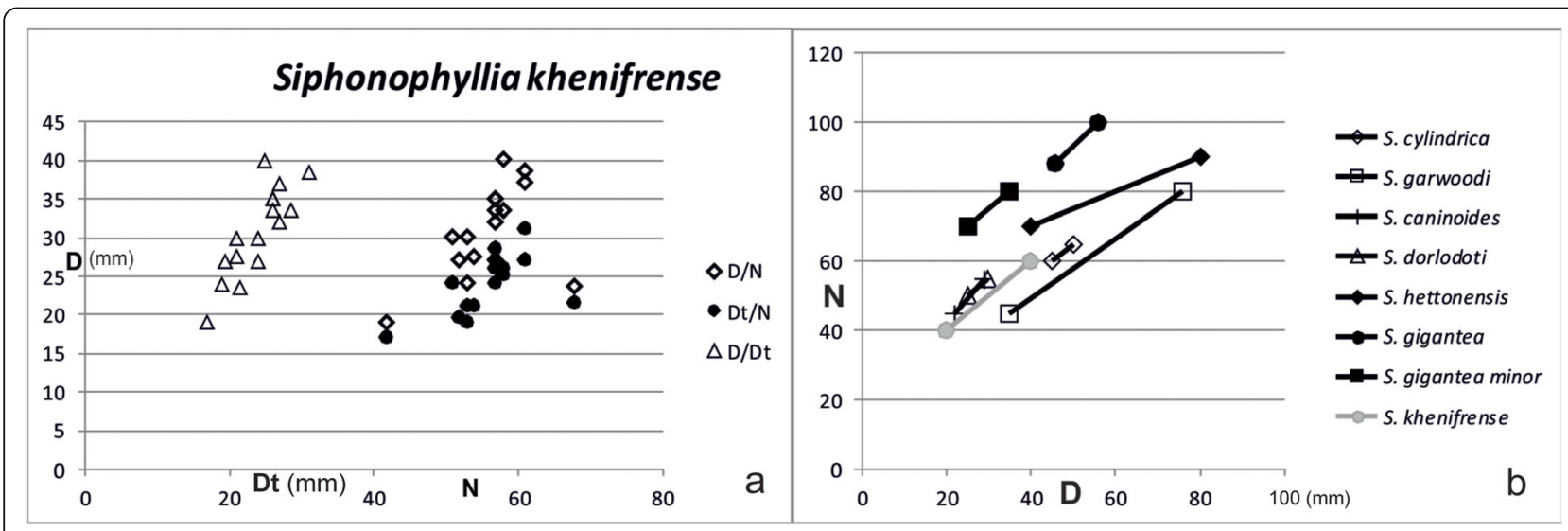

Fig. 5 a Plot of corallite diameter (D) and tabularium diameter (Dt) versus number of septa (N) in Siphonophyllia khenifrense sp. nov.; b Plot of ranges of species of Siphonophyllia 


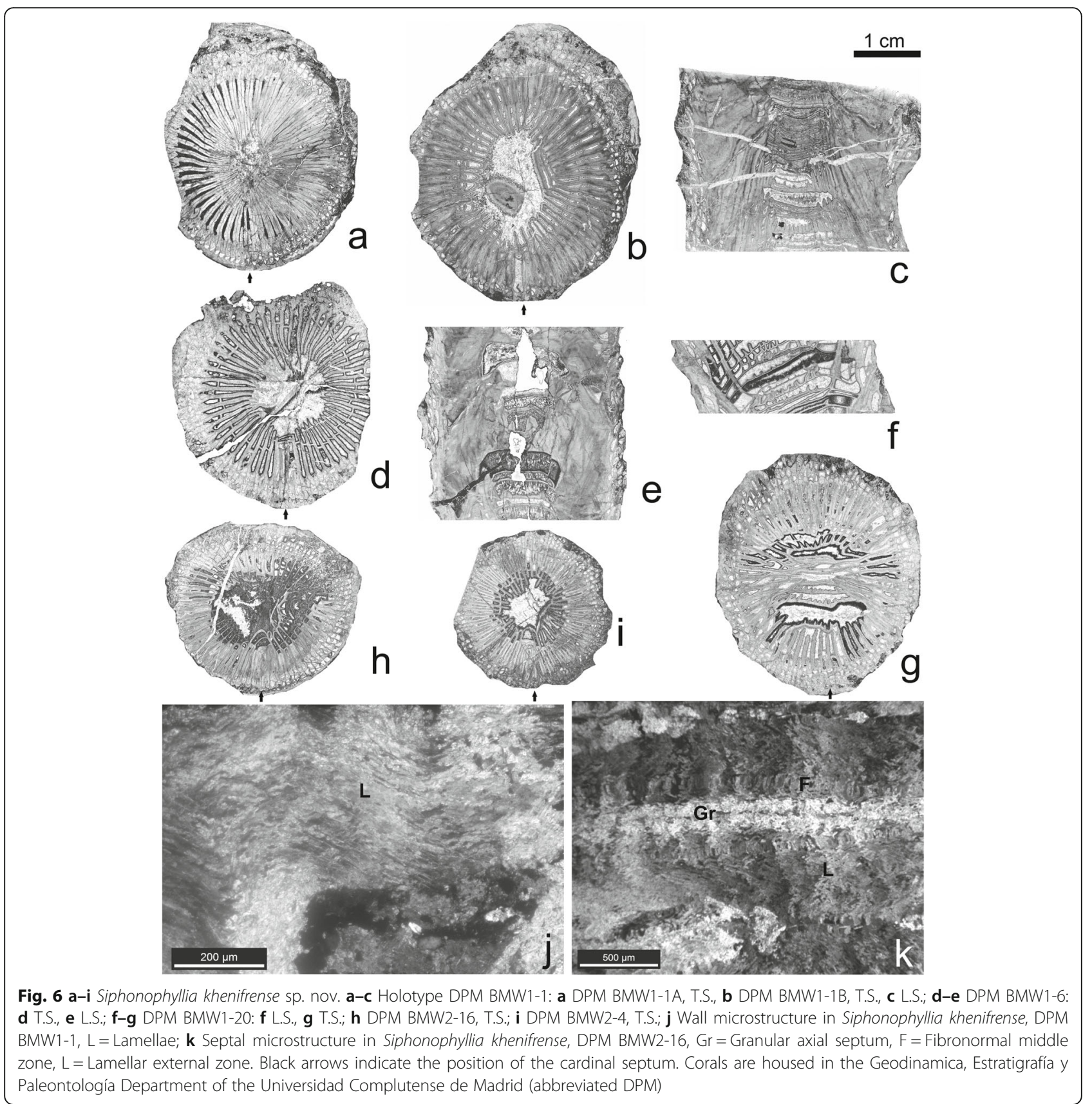

strongly thickened in the tabularium but are thin in the dissepimentarium; septa can be slightly thicker in cardinal quadrants and thinner in counter quadrants (Fig. 6h). The minor septa are also thickened where they penetrate slightly into the tabularium, but not as thick as majors; in the dissepimentarium they are thin. They are variable in length, from $1 / 4$ to $1 / 3$ length of majors. The cardinal septum is slightly shorter in most mature corallites and located in a closed small cardinal fossula (Fig. 6b, d, h). It is often flanked by two major septa which are shorter than the others (Fig. 6b). Counter septum is inconspicuous, but shorter in late adult stages.
The dissepimentarium is narrow (typically $1 / 10$ to $1 / 5$ corallite diameter) and mainly composed of interseptal regular dissepiments. The dissepiments are more irregular in the external part of the dissepimentarium, with occasional lonsdaleoid dissepiments (Fig. 6b). Typically 3 to 6 rows of slightly angular concentric dissepiments are present in the dissepimentarium (Fig. 6b, d, g, h, i). In longitudinal section, the dissepiments are small and elongate. They are declined to the tabularium from $60^{\circ}$ to $70^{\circ}$ (Fig. 4c, e).

The tabulae are mostly complete flat domes with some splitting; horizontal, medially sagging and convex tabulae 
can be present, sloping down peripherally to prominent gutters (Fig. 6c, e, f). They are relatively widely spaced numbering between 6 and 12 each centimeter.

The wall microstructure is microlamellar (Fig. 6j), as well as the septal stereoplasm and thickenings of tabulae and dissepiments. The septal mesoplasm is granulofibrous (Fig. 6k) with incipient development of microtrabeculae. The tabulae and dissepiments are microgranular.

Remarks: The main diagnostic features of the new species are the large tabularium diameter for corallites of moderate size, and fewer major septa than many species of the genus. The regular concentric interseptal dissepiments distinguish $S$. khenifrense from older Tournaisian species in Belgium (Poty 1989), such as S. cylindrica hastariense (Salée 1913) and S. rivagensis Poty and Boland 1996; Boland 1997, and other coeval early Visean species, such as S. cylindrica Scouler 1844 (Lewis 1927), S. caninoides (Sibly 1906) and S. garwoodi Mitchell 1980, from UK (Garwood 1916; Somerville et al. 1986; Mitchell 1989), which have conspicuous lonsdaleoid dissepiments and minor septa often reduced to short pegs on the dissepiments and tabularium wall or absent. The early Visean species S. hettonensis (Wilmore 1910) and S. gigantea (Michelin 1843) show also low development of lonsdaleoid dissepiments, but much larger size and number of septa than S. khenifrense (Fig. 5b).The late Visean and Serpukhovian species S. samsonensis (Salée 1913) $(=$ S. benburbensis Lewis 1927) from Western Europe and North Africa (Smyth 1925; Hill 1938; Dixon 1970; Hubbard 1970; Semenoff-Tian-Chansky 1974, 1985; Poty 1981; Poty and Hannay 1994; Somerville 1997; Said 2005; Rodríguez and Somerville 2007; Aretz 2010, 2011; Denayer et al. 2011; Rodríguez et al. 2012, 2013, 2016b; Said et al. 2013) differs by its larger dimensions, greater number of major septa and short discontinuous minor septa. The only caninoid coral described in the early Visean from the High Atlas is Caninophyllum skouraense Poty in Izart et al. 1989, which shows clear differences with Siphonophyllia by the presence of very thick and long septa and absence of lonsdaleoid dissepiments.

Distribution: Only known from Azrou-Khenifra Basin, Morocco. The genus Siphonophyllia is almost cosmopolitan. It is widely distributed from North America (where it is present but scarce in the early Mississippian) to Japan. The only continent in low latitudes where it is not recorded is Australia.

\section{Family Zaphrentoididae Schindewolf 1938}

\section{Genus Sychnoelasma Lang et al. 1940}

Diagnosis (Falces and Rodríguez 2002): Small solitary ceratoid coral, cardinal side convex; calice moderately deep, bell-shaped; septa numerous, long, radial, their axial ends fused to form thickened wall to long cardinal fossula, deepest at periphery and widest at axial end; containing a short cardinal septum, thinning and shortening in later stages of development; minor septa may be long, tabular floors convex, sagging deeply in fossula; tabulae complete or incomplete; absence of dissepiments; fibronormal septal microstructure.

Sychnoelasma urbanowitschi (Stuckenberg 1895) (Figs. 7 and $8 \mathrm{a}-\mathrm{d})$

Material: 3 specimens (DPM BMW1-12, 15, 19), 4 transverse sections.

Description: Corallites having $16-20 \mathrm{~mm}$ corallite diameter and 42 to 50 major septa (Figs. 7 and 8 a-c). The Ba Moussa West specimens exhibit typical features of the species with short cardinal septum in long parallel-sided cardinal fossula which reaches the axis where it expands slightly, and strong thickening of major septa and minor septa, the latter less so than the majors. The minor septa are typically $1 / 3$ length of majors and similar in length with the cardinal septum. Major septa are usually more dilated in cardinal quadrants than counter quadrants. The wall microstructure is lamellar; the septal microstructure is fibronormal with a tendency to water-jet in the inner portions (Fig. 8d).

Remarks: It differs from the upper Tournaisian $S$. hawbankense Mitchell and Somerville 1988, which has longer minor septa and fewer major septa in corallites of smaller diameter and from S. konincki (Milne-Edwards and Haime 1850) by its larger dimensions and greater number of septa. Ba Moussa West specimens of Sychnoelasma urbanowitschi are smaller than the type material and show intermediate features with $S$. hawbankense, but the differences are by far larger than with the type material of the latter.

Distribution: The genus Sychnoelasma is typically Tournaisian and early Visean. It is distributed from China to North America, with its maximum abundance and diversity in the late Tournaisian from the western

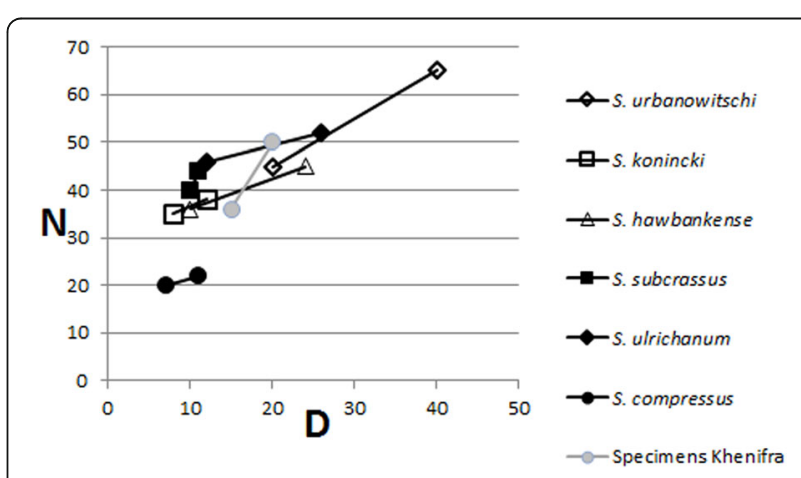

Fig. 7 Plot of corallite diameter (D) versus number of septa $(N)$ in species of Sychnoelasma 


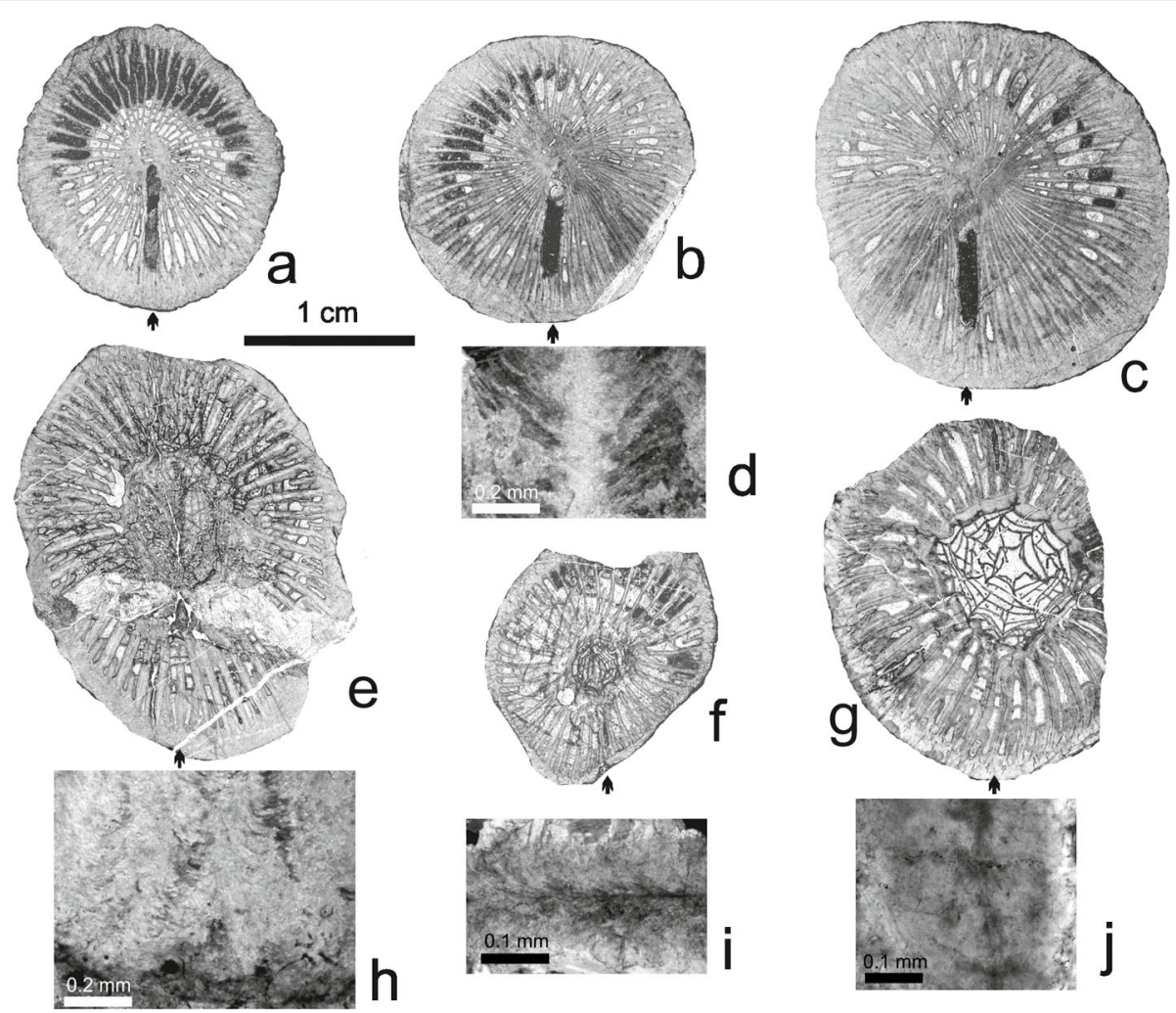

Fig. 8 a-d Sychnoelasma urbanowitschi (Stuckenberg): a DPM BMW1-12, T.S., b DPM BMW1-15, T.S., c DPM BMW1-19, T.S., d Septal fibrous microstructure; e, i, j Cravenia lamellata Howell: e DPM BMW1-23, T.S., i Water-jet fibrous septum, $\mathbf{j}$ Fibrous inner border of septum; $\mathbf{f}$ Cravenia tela Hudson DPM BMW2-5, T.S.; g-h Cravenia rhytoides Hudson: $\mathbf{g}$ DPM BMW1-4, T.S., h DPM BMW1-4 lamellar microstructure at the wall. Black arrows indicate the position of the cardinal septum

Palaeotethys. Sychnoelasma urbanowitschi is recorded from lower Visean strata in Western Europe (Germany, France, Belgium, UK and Ireland) (Fontaine 1980; Poty 1981; Vuillemin 1990; Somerville 1994; Weyer 2000; Denayer et al. 2011). Vassiljuk (1960), Sayutina (1976) and Fedorowski (1981) also record it from Eastern Europe (Ukraine and Urals) in the early Visean. Sychnoelasma sp. close to $S$. urbanowitschi is recorded in Serpukhovian rocks in Guadiato Valley, SW Spain (Falces and Rodríguez 2002), but the corals occur in olistoliths and are inferred to have been derived from older lower Visean strata no longer exposed.

Family Verbeekiellidae Schouppé and Stacul 1955

Genus Cravenia Hudson 1928

Diagnosis (after Hill 1981): Small solitary cornute coral, fossula on convex side, axial structure, a welldefined column with median plate produced into a cusp on cardinal side and continuous in young stages with cardinal septum, which withdraws in late stages; numerous thin septal lamellae radiate with some curvature from median plate; tabellae within column more steeply declined than those between column and the wall; septa somewhat dilated in early stages, with their bases contiguous to form, narrow peripheral stereozone; no dissepiments; septal microstructure is composed of fibronormal to water-jet mesoplasm and lamellar stereoplasm.

Distribution: The genus Cravenia has been recorded exclusively in the Palaeotethys. It is absent in North America, Australia and Japan. It has been mainly recorded in the Tournaisian-Visean transition from Western Europe (Poty 1985; Somerville et al. 1986; Vuillemin 1990), but there are records also in the Urals (Degtiarev 1972) and South China (Jia and Xu 1977).

Cravenia rhytoides Hudson 1928 (Figs. 8g, h and 9)

Material: 1 specimen (DPM BMW1-4), 1 transverse section.

Description: Cravenia rhytoides having $17 \mathrm{~mm}$ corallite diameter and 34 dilated major septa with long less dilated minor septa. The Ba Moussa West specimen exhibits typical features of the species, with dense and wide axial structure $2 / 5$ of corallite diameter with a distinct medial lamella, absence of dissepiments and a thick inner wall separating the septa from the axial structure. The minor septa are typically 2/5 length of majors and dissepiments are absent. Wall is microlamellar (Fig. 8h) 


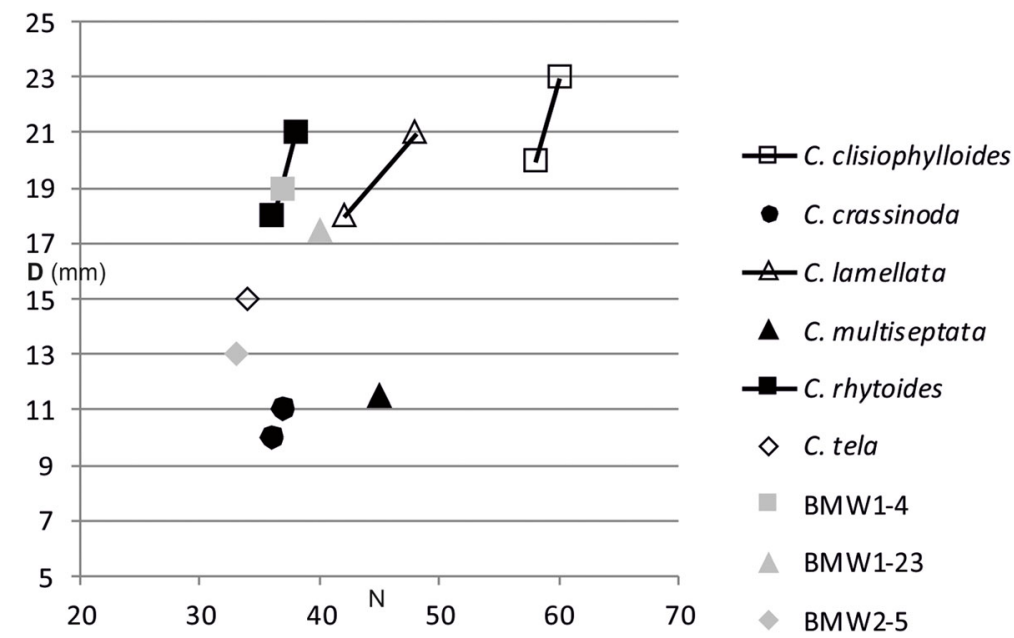

Fig. 9 Plot of ranges of corallite diameter (D) versus number of septa (N) in species of Cravenia

as well as the inner wall, thickenings on tabulae and dissepiments and the septal stereoplasm. The mesoplasm shows fibronormal microstructure.

Remarks: The Ba Moussa West specimen differs from the holotype in slightly smaller diameter axial structure, thicker septa and inner wall and slightly longer minor septa. C. rhytoides differs from $C$. tela by its larger axial structure and larger corallite diameter, and from $C$. lamellata by having fewer major septa and smaller corallite diameter.

\section{Cravenia tela Hudson 1928 (Figs. 8f and 9)}

Material: 1 specimen (DPM BMW1-23), 1 transverse section.

Description: Cravenia tela having $13 \mathrm{~mm}$ corallite diameter and 33 major septa. Minor septa 1/2 length of majors. Both types of septa are not dilated. Narrow axial structure (3 $\mathrm{mm}$ in diameter, $1 / 4$ of corallite diameter) composed of densely packed conical tabulae and radial lamellae, with well-marked median lamella and bounded by a middle thick inner wall. Dissepiments are absent. Wall is microlamellar as well as the inner wall, thickenings on tabulae and dissepiments and the septal stereoplasm. The mesoplasm shows fibronormal to water-jet microstructure.

Remarks: The Ba Moussa West specimen exhibits typical features and dimensions of the holotype, but the axial structure is smaller and shows a thicker inner wall separating the axial structure from tabularium. Although it has similarity with $C$. rhytoides in the number of major septa, it can be distinguished by its smaller size, lacking dilation of major and minor septa, and having a narrower axial structure.

Cravenia lamellata Howell 1938 (Figs. 8e, i, j and 9)
Material: 1 specimen (DPM BMW2-5), 1 transverse section.

Description: Cravenia lamellata having $19 \mathrm{~mm}$ corallite diameter and 44 dilated major septa, with wide axial structure $1 / 3-2 / 5$ of corallite diameter without a medial lamella, absence of dissepiments and a thick inner wall separating the septa from the axial structure. Wall is microlamellar as well as the inner wall, thickenings on tabulae and dissepiments and the septal stereoplasm. Septal mesoplasm shows a water-jet organization of fibers (Fig. 8i, j).

Remarks: The Ba Moussa West specimen exhibits typical features of the species with a wide axial structure of $6 \times 8 \mathrm{~mm}^{2}, 1 / 3-2 / 5$ corallite diameter, more complex than in C. tela, with 6-8 rows of tabellae and 12 septal lamellae and a prominent short thin median plate. The minor septa are typically $2 / 5$ length of majors. The cardinal septum is short, as in the holotype. It can be distinguished from $C$. rhytoides by the much larger number of major septa, and wide axial structure without medial lamella.

Subclass Tabulata Milne-Edwards and Haime 1850

Order Favositida Wedekind 1937

Family Michelinidae Waagen and Wentzel 1886

Genus Turnacipora Lafuste and Plusquellec 1985

Diagnosis (after Lafuste and Plusquellec 1985): Micheliniid genus with cerioid corallites, characterized by microlamellar wall. Without spines. Incomplete or vesiculous axial tabulae; globose peripheral tabulae, usually distinct. Pores on the faces or the vertices of the walls. Increase by basal buddings in the borders of the colonies; intercorallite budding very rare.

Turnacipora megastoma (Phillips 1836) (Fig. 10a-e). 

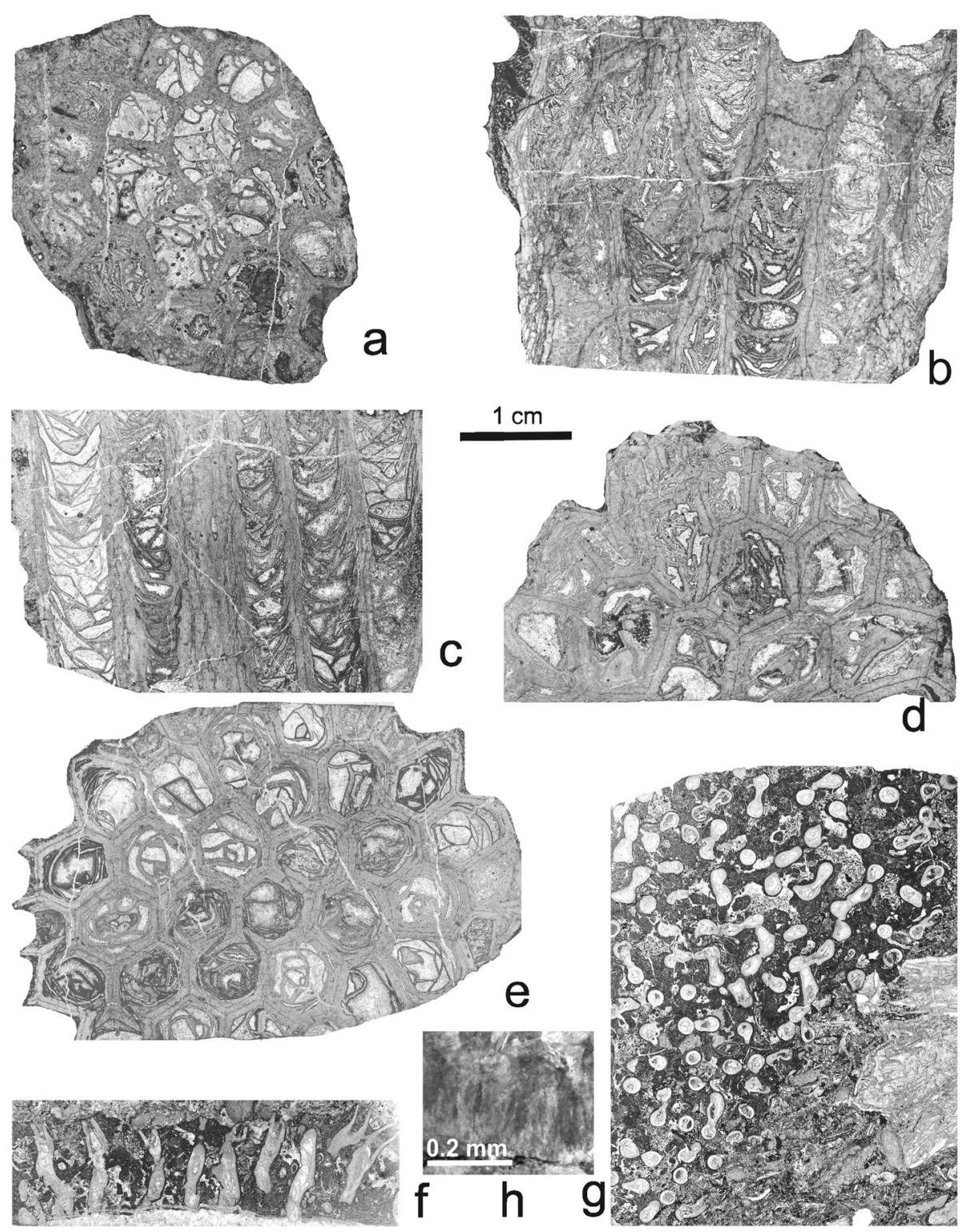

Fig. 10 a-e Turnacipora megastoma (Phillips): a DPM BMW1-3b, T.S., b, d DPM BMW1-26, b L.S., d T.S., c, e DPM BMW1-27, c L.S., e T.S.; $\mathbf{f}-\mathbf{h}$ Pleurosiphonella crustosa Tchudinova: f DPM BMW1-24, L.S., g DPM BMW1-24, T.S., h DPM BMW1-24, fibrous microstructure of the wall

Material: 6 specimens (BMW1-3, 1-25, 1-26, 1-27, 128, 1-29). Ten transverse and four longitudinal sections.

Description: Massive cerioid colonies mostly fragmented. Maximum dimensions of colonies recorded are $15 \mathrm{~cm}$ in diameter and $8 \mathrm{~cm}$ in height. Single corallites are 4-7 sided, variable in size, $12 \mathrm{~mm}$ in maximum diameter, and having walls $0.5-2.2 \mathrm{~mm}$ thick (Fig. 10a-e). Mural pores scarce, both, at corners of corallites and on corallite wall sides, $0.2-0.4 \mathrm{~mm}$ in diameter and commonly obliterated by thickenings of the wall. Tabulae mostly incomplete, mostly concave upwards, locally convex upwards and densely packed (Fig. 10b, c). All structures show conspicuous thickenings. Microstructure of the median dark line microgranular. Microstructure of wall and tabular thickenings microlamellar.

Remarks: Lafuste and Plusquellec (1985) proposed the new genus Turnacipora as different from Michelinia by its microlamellar microstructure, and included in that genus the species $M$. favosa (type) and M. megastoma. Subsequently, Tourneur et al. (1989) included in Turnacipora only the type species and included the species $T$. megastoma in a general term of "Michelinia sensu lato" because of the absence of detailed microstructural studies on it. As the specimens from Ba Moussa West show identical microstructure to that described by Lafuste and Plusquellec (1985) in T. favosa, we follow their statement on the 
generic assignation of T. megastoma. The specimens from Ba Moussa West show microlamellar microstructure and identical dimensions as the specimens from the British Isles and Belgium. The only differences are a conspicuous thickening of most structures and less development of peripheral, steeply inclined vesicular tabulae. The species is typical for the late Tournaisian and early Visean from Europe and it has been also mentioned in an identical stratigraphical position in the Central Sahara (Lafuste 1983), but the Saharian specimen shows smaller corallites and includes fibrous layers in the microstructure.

Distribution: T. megastoma is an index fossil from the late Tournaisian and early Visean. It is common in the British Isles (Vaughan 1905; Matley and Vaughan 1906; Mitchell 1973; Somerville et al. 1986), Iran (Ogar et al. 2013), Kuznets Basin and Altai (Dobrolyubova et al. 1966), and Himalaya (Wang et al. 2003) and less common in the same ages in Belgium (Tourneur et al. 1989).

Order Auloporida Sokolov 1947

Family Syringoporidae de Fromentel 1861

Genus Pleurosiphonella Tchudinova 1970

Diagnosis (after Tchudinova 1970): Colonies fasciculate, formed of cylindrical, slightly curved corallites usually arranged closely or at intervals equal to onehalf or less than one-half of corallite diameter. Corallites connected by very sparse, irregularly arranged tubules. Walls of corallites thick, with well-defined fibrous sclerenchyme, covered with concentrically rugose epitheca. Tabulae sparse, deeply infundibuliform, with distinct lateral hollow tubules. Septal spinules sparse or absent. Increase lateral.

Pleurosiphonella crustosa Tchudinova 1970 (Fig. 10f-h). Material: 1 specimen (BMW1-24). Two transverse and one longitudinal section.

Description: Fasciculate colony, composed of parallel corallites. Rounded corallites from $1.3 \mathrm{~mm}$ to $1.5 \mathrm{~mm}$ in diameter. Corallites closely spaced (about $2 \mathrm{~mm}$ apart). Walls thick, 0.25-0.35 mm (Fig. 10f, g). Microstructure typically fibrous (Fig. 10h). Scarce connecting tubules. Tabulae infundibuliform, with laterally placed syrinx (Fig. 10f). Septal spines absent.

Remarks: The presence of infundibuliform tabulae with laterally placed syrinx and the fibrous wall allow the identification of the studied specimen as Pleurosiphonella. Moreover, the diameter of corallites, diameter of the wall and absence of septal spines are identical to the type species $P$. crustosa. The only difference is the separation of corallites that is slightly higher in the specimen from Ba Moussa West than in the Caucasian species and might be due to ecological control. The type species is somewhat older than our specimen (late Tournaisian compared to early Visean).
Distribution: The genus Pleurosiphonella occurs in North America from Tournaisian to Serpukhovian. In Western Palaeotethys, it has been cited from the lower Tournaisian from Belgium (Tourneur et al. 1989), from the lower Visean Kohlenkalk (Chadian) in Germany (Weyer 1993, 2000) associated with Cyathoclisia modavensis (Salée 1913), with Sychnoelasma urbanowitschi and Siphonophyllia garwoodi in the succeeding Arundian strata. In the Middle Palaeotethys, it has been recorded in the upper Tournaisian and lower Visean from Moscow Basin, Urals (Tchudinova 1986), Transcaucasia (Tchudinova 1970), Tian-Shan (Ogar 2006) and Darwas (Leleshus 1991). In most cases, it is associated with Turnacipora and Siphonophyllia.

\section{Palaeobiogeographic significance of coral faunas (Table 2)}

At least four transgressive phases were differentiated in the Azrou-Kenifra Basin by Huvelin and Mamet (1997) which were related with fault activity and resedimentation on the margins of tectonic blocks (Table 1). The early Visean corals at Ba Moussa West are the oldest occurrence in this basin, and are an important fauna differentiated from the commonly described faunas in late Visean beds of the western margin of the basin at Sidi Lamine and Tabainout (Aretz and Herbig 2010; Somerville et al. 2012, 2013; Said et al. 2013), as well as in the northern part of the basin at Adarouch (Said et al. 2007, 2013) (Fig. 1).

The early Visean age in the MFZ9 is older than the previously considered age by Huvelin and Mamet (1997) for North Ba Moussa point 1 (Mamet's Zone 11 or equivalent MFZ10), in spite of foraminifer species that was based on their zonal correlation, Earlandia vulgaris and Eotextularia diversa, are also occurring in samples from BMW1 and BMW2 (assigned here to the MFZ9).

The Ba Moussa West succession is a resedimented body of shale, siltstone and limestone with early Visean microfossils and corals, indicating that the probable age of sedimentation was very close to that of skeletal growth of the components. The corals and microfossils correspond to shallow-water taxa dwelling on a neighbouring sedimentary relief. The coralline assemblage shows a distinctive dominance of solitary rugosans, the absence of colonial rugosans and occurrence of colonial tabulate corals. Moreover, the solitary forms are dominated by Siphonophyllia khenifrense and Sychnoelasma urbanowitschi, and the tabulate coral Turnacipora megastoma. A similar association of Siphonophyllia aff. garwoodi and Sychnoelasma urbanowitschi is known from the early Visean of the Laval syncline in Normandy (N. France), although with colonial rugosans there (Solenodendron spp.; Fontaine 1980; Vuillemin 1990). This colonial genus is not recorded in the Azrou-Khenifra Basin first until the late Visean (Said 2005; Somerville et al. 2016). 
Table 2 Distribution of corals from the lower Visean in the main areas of Western Palaeotethys. The Taurides have been included as external near group. KH: Azrou-Khenifra, TA: Tafilalt, BR: Britain, FR: France, BE: Belgium, GE: Germany, PO: Poland, DO: Donetz, Tau: Taurides, X: Present. Data mainly taken from Vassiljuk (1960), Fedorowski (1981), Poty (1981), Somerville et al. (1986), Mitchell (1989), Vuillemin (1990), Weyer (2000), Denayer et al. (2011), Aretz et al. (2013), Denayer (2015) and unpublished

\begin{tabular}{|c|c|c|c|c|c|c|c|c|c|}
\hline Genera & $\mathrm{KH}$ & TA & $B R$ & $F R$ & $\mathrm{BE}$ & GE & $\mathrm{PO}$ & DO & $\mathrm{Tau}$ \\
\hline Amplexus & & & & & $x$ & $x$ & & & \\
\hline Amygdalophyllum & & & & & $x$ & & & & $x$ \\
\hline Aulokoninckophyllum & & & & $x$ & & & & & \\
\hline Axophyllum & & & $x$ & & $x$ & $x$ & & & \\
\hline Bifossularia & & & & $x$ & & & & $x$ & $x$ \\
\hline Calmiussiphyllum & & & & & & & & & $x$ \\
\hline Calophyllum & & & & & & $x$ & & & \\
\hline Caninia & & & $x$ & & & $x$ & $x$ & $x$ & $x$ \\
\hline Caninophyllum & & & $x$ & & $x$ & & & & $x$ \\
\hline Carruthersella & & & $x$ & & $x$ & $x$ & & & \\
\hline Clisiophyllum & & & $x$ & $x$ & $x$ & $x$ & & & \\
\hline Corphalia & & & & & $x$ & & & & \\
\hline Cravenia & $x$ & $x$ & $x$ & $x$ & $x$ & & & & \\
\hline Cyathaxonia & & $x$ & $x$ & & $x$ & $x$ & & & \\
\hline Cyathoclisia & & & & & $x$ & $x$ & & & \\
\hline Dorlodotia & & & $x$ & & & $x$ & & & \\
\hline Drewerelasma & & & & & & $x$ & & & \\
\hline Eokoninckocarinia & & & & & & & & & $x$ \\
\hline Haplolasma & & & $x$ & & $x$ & & & & \\
\hline Heterophyllia & & & $x$ & & $x$ & $x$ & & & \\
\hline Hexaphyllia & & & $x$ & & $x$ & $x$ & & & \\
\hline Keyserlingophyllum & & & & & $x$ & $x$ & & & \\
\hline Koninckophy/lum & & $x$ & $x$ & & & $x$ & $x$ & & \\
\hline Kueichouphyllum & & & & & & & & & $x$ \\
\hline Merlewoodia & & & & $x$ & $x$ & & & & \\
\hline Michelinia & & & $x$ & $x$ & $x$ & $x$ & & $x$ & \\
\hline Multithecopora & & & $x$ & $x$ & $x$ & & & & \\
\hline Palaeosmilia & & & $x$ & $x$ & $x$ & $x$ & $x$ & & \\
\hline Pentaphyllum & & $x$ & & & & $x$ & & & \\
\hline Pleurosiphonella & $x$ & & & & & $x$ & & & \\
\hline Rotiphyllum & & & & & $x$ & $x$ & & & \\
\hline Rylstonia & & $x$ & & & $x$ & $x$ & & $x$ & \\
\hline Siphonodendron & & & $x$ & & & $x$ & $x$ & $x$ & \\
\hline Siphonophyllia & $x$ & $x$ & $x$ & $x$ & $x$ & $x$ & $x$ & $x$ & $x$ \\
\hline Solemnophyllum & & & & $x$ & & & & & \\
\hline Solenodendron & & & $x$ & $x$ & & $x$ & & & \\
\hline Spirophyllum & & & $x$ & & & & & & \\
\hline Sutherlandia & & & & & & $x$ & & & \\
\hline Sychnoelasma & $x$ & $x$ & $x$ & $x$ & $x$ & $x$ & $x$ & & \\
\hline Syringopora & & $x$ & $x$ & & $x$ & $x$ & $x$ & & \\
\hline Turnacipora & $x$ & & $x$ & & $x$ & & & & \\
\hline Ufimia & & & & & $x$ & $x$ & $x$ & & \\
\hline Uralinia & & & & & & $x$ & & & $x$ \\
\hline Zaphrentites & & $x$ & & & $x$ & & $x$ & $x$ & $x$ \\
\hline
\end{tabular}

The Ba Moussa West assemblage has 'affinities' with the early Visean RC4ß2 subzone of Poty et al. (2006). However, none of the seven listed key taxa of this subzone are recorded in Morocco, although the genera Siphonophyllia, Cravenia and Sychnoelasma are present. Perhaps of greater significance though, is that whereas $S$. hawbankense is only recorded in the underlying upper Tournaisian RC4ß1 subzone of Poty et al. (2006), a new taxon S. hawbankense subsp. A which starts in this subzone, extends into RC4ß2 subzone (see Fig. 9 in Poty et al. 2006). Unfortunately, this subspecies is not described or figured in the 2006 paper. The strong possibility exists though, that this corresponds to the small $S$. urbanowitschi of Ba Moussa, which represents the transition to larger typical forms in RC5 Zone.

The Ba Moussa West coral fauna, although quite restricted in its diversity, nevertheless, contains typical elements of the Western European coral province of Fedorowski (1981) and Sando (1990) (which includes North Africa and Nova Scotia) (Fig. 11). In particular, the dominance of solitary rugosa and tabulate corals is a feature of the early Visean assemblages which are recognised in NW Europe: Normandy ( $\mathrm{N}$ France), southern Belgium, SW Province, North Wales, Craven Lowlands and South Cumbria (Great Britain), and Dublin Basin (Ireland) (Poty 1981; Mitchell 1989; Vuillemin 1990; Somerville 1994; Denayer et al. 2011). Similar early Visean faunas with solitary rugosans are known in the eastern part of the Anti-Atlas region at Tafilalt (Aretz et al. 2013; Denayer 2015) in eastern Morocco and in the Béchar Basin in Algeria (Semenoff-Tian-Chansky 1974, 1985). The late Tournaisian to early Visean rugose coral fauna from Tafilalt is richer than that from $\mathrm{Ba}$ Moussa. It is dominated by solitary genera, both undissepimented (Sychnoelasma, Cravenia) and dissepimented (Bifossularia, Cyathoclisia, Clisiophyllum, Siphonophyllia, Palaeosmilia, Amygdalophyllum), and is lacking colonial rugosans (Aretz et al. 2013; Denayer 2015).

It was previously considered that since the AzrouKhenifra Basin only had late Visean and younger coral assemblages (Aretz and Herbig 2010; Said et al. 2013; Rodríguez et al. 2016a), so too the Jerada Basin in NE Morocco (Aretz 2010), they were isolated from other marine basins in the early Visean. Connections among the Azrou-Khenifra Basin, NW Europe, Tafilalt, and other Saharian basins in Algeria (Béchar Basin) were open from the Asbian and Brigantian (late Visean). The Ba Moussa West corals, foraminifers and conodonts suggest that marine seaways were available for migrations between the Azrou-Khenifra Basin and other regions from the early Visean. Similar early Visean faunas with solitary rugosans are known in the eastern part of the Anti-Atlas region at Tafilalt (Aretz et al. 2013; Denayer 


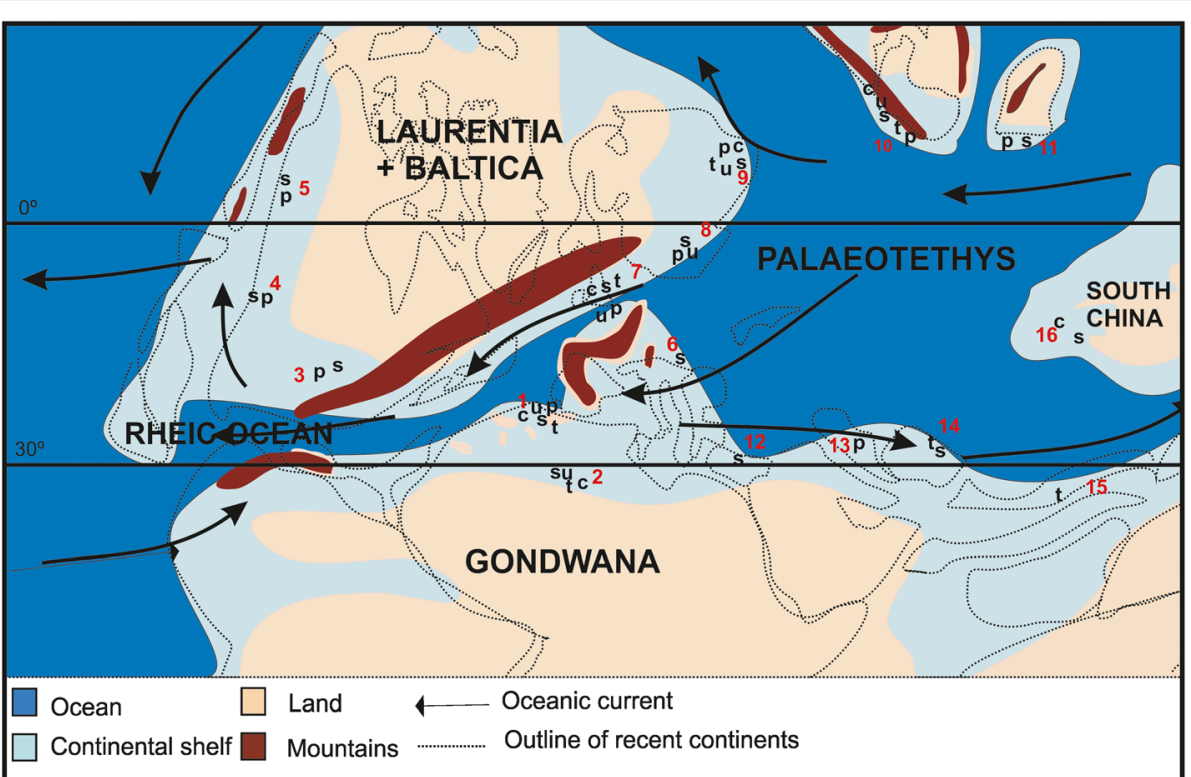

Fig. 11 Palaeogeographic distribution of the coral taxa recorded in Ba Moussa West in the Palaeotethys region and around Laurentia and Baltica (modified after Webb 2002). s Siphonophyllia, u Sychnoelasma urbanowitschi, c Cravenia, t Turnacipora, p Pleurosiphonella. 1. Ba Moussa West, 2. Tafilalt, 3. Midcontinent, 4. Western Interior, 5. Canadian Rockies, 6. Carnic Alps, 7. Western Europe, 8. Eastern Europe, 9. Moscow Basin, 10. Ural Mountains, 11. Tian-Shan (Northwest China), 12. Turkey, 13. Transcaucasia, 14. Iran, 15. Himalaya, 16. South China

2015), in eastern Morocco and in the Béchar Basin in Algeria (Semenoff-Tian-Chansky 1974, 1985). The marine connections between NW Europe and the southern part of the Azrou-Khenifra Basin is supported by similar early Visean assemblages recognized in NW Europe with abundant solitary rugose and tabulate corals, but with colonial rugosans: Normandy ( $\mathrm{N}$ France), southern Belgium, SW Province, North Wales, Craven Lowlands and South Cumbria (Great Britain), and Dublin Basin in Ireland (Poty 1981; Mitchell 1989; Vuillemin 1990; Somerville 1994; Denayer et al. 2011).

In relation to the tabulate corals, the tabulate Turnacipora megastoma in the Ba Moussa West assemblage was also known from Central Saharian basins, but also from the Chadian-Arundian (early Visean) locations in NW Europe (UK, Ireland, France, Germany?) (Lafuste 1983). The occurrence of Pleurosiphonella crustosa is the first report in North Africa and suggests marine connection with the Urals. It was first described from the upper Tournaisian of Transcaucasia (Tchudinova 1970) and its age range extends here slightly into the early Visean. The dispersion between SW Asia (Armenia, Taurides and Alborz) and the Azrou-Khenifra Basin, via Tafilalt, Béchar and Sinai, is poorly established. Some solitary rugosans (Siphonophyllia) are common to all areas, but others, such as Kueichouphyllum and the colonial form Eokoninkocarinia, indicative of Asiatic affinity are clearly absent in Morocco (Denayer 2015).

\section{Conclusions}

A new early Visean coral assemblage has been discovered transported in the rhythmic facies deposits of the southern part of the Azrou-Khenifra Basin, northwest of Khenifra, Morroco. The Ba Moussa West coral fauna includes Siphonophyllia khenifrense sp. nov., Sychnoelasma urbanowitschi, Cravenia lamellata, Cravenia tela, Cravenia rhytoides, Turnacipora megastoma and Pleurosiphonella crustosa. The early Visean age of the coral assemblage is supported by microfossil data, which confirms a previous hypothesis that indicated a first transgression during the early Visean in the Carboniferous of the Meseta. The allochthonous coral assemblage was recovered from coarse-grained proximal limestone debris flow and turbidite beds within a fault-bounded rhythmic unit in the eastern part of the basin. No evidence remains of the former early Visean shallow-water platform from which the corals were derived. All other in situ platform carbonate rocks around the southern margin of the Azrou-Khenifra Basin are of late Visean (AsbianBrigantian) age. The early Visean Ba Moussa West coral fauna can be compared with that from the Saharian basins of SE Morocco and Algeria. Most of the genera and species in the Ba Moussa West assemblage are identical to those in Western Europe, indicating possible marine connections. The new rugose species described, Siphonophyllia khenifrense, is probably endemic to North Africa. Its ecological niche in NW Europe was occupied by $S$. cylindrica or $S$. aff. garwoodi. 
The microfossil determinations provide greater precision in the age dating of the Ba Moussa West limestones. The foraminiferal assemblages from BMW1 can be attributed to the lowermost Visean (MFZ9). Similarly, the conodont fauna recovered from the same beds, although sparse, suggests a late Tournaisian to early Visean age.

\section{Abbreviations}

BMW: Ba Moussa West; CAl: Conodont alteration index; DPM: Geodinamica, Estratigrafía y Paleontología Department of the Universidad Complutense de Madrid; L.S.: Longitudinal section; MFZ: Mississippian Foraminiferal Zone; T.S.: Transverse section; TAl: Thermal alteration index; TR: Transgression

\section{Acknowledgements}

The authors thank the discussions on the regional geology and the location of the studied outcrops to Prof. M. El Houicha (Université Chouaïb Doukkali). We thank the technicians of the Laboratory or the Area de Paleontología of the Complutense University and Instituto de Geociencias for the preparation of thin sections. JS-L would like to express their gratitude to A.J. Quintana García (Scientific-Technical Services, University of Oviedo) for their assistance with the scanning electron microscope. This study is a contribution to the IGCP 652.

\section{Authors' contributions}

SR participated in the sampling and study of rugose corals and sedimentology. IDS collaborated in the sampling and study of rugose corals and sedimentology. PC carried out the sampling and study of foraminifera and algae and sedimentology. JS-L carried out the study of conodonts. IC participated in the study of the tabulate corals. FG carried out the sampling and study of palynomorphs. IS participated in field works and organization of expedition. MEH located the outcrops and provided information on the regional geology. All authors participated in the interpretation of results and writing the paper. All authors read and approved the final manuscript.

\section{Funding}

This study was funded by projects CGL2012-30922 and CGL2016-78738-P of the Spanish Government.

\section{Availability of data and materials}

Corals: Department of Geodinamics, Stratigraphy and Paleontology, Universidad Complutense de Madrid. Foraminifera: Institut of Geosciences of Madrid, CSIC. Conodonts: Department of Geology, Universidad de Oviedo. Palinomorphs: Department of Earth Sciences, Universidad de Huelva.

\section{Competing interests}

The authors declare that they have no competing interests.

\section{Author details}

'GEODESPAL, Universidad Complutense de Madrid, c/José Antonio Novais 12, 28040 Madrid, Spain. ${ }^{2}$ Instituto de Geociencias (CSIC, UCM), c/ José Antonio Novais 12, 28040 Madrid, Spain. ${ }^{3}$ UCD School of Earth Sciences, University College Dublin, Belfield, Dublin 4, Ireland. ${ }^{4}$ Departmento de Geología, Universidad de Oviedo, Arias de Velasco s/n, 33005 Oviedo, Spain. ${ }^{5}$ Institute of Paleobiology, Warsaw, Poland. ${ }^{6}$ Dpto. de Ciencias de la Tierra, Universidad de Huelva, Avda. Fuerzas Armadas s/n, Campus de El Carmen, 21071 Huelva, Spain. ${ }^{7}$ Laboratoire de Géodynamique et Géomatique, Faculté des Sciences, Université Chouaïb Doukkali, BP.20, 24000 El Jadida, Morocco.

Received: 16 April 2019 Accepted: 19 November 2019

Published online: 11 February 2020

\section{References}

Aretz, M. 2010. Rugose corals from the upper Visean (Carboniferous) of the Jerada massif (NE Morocco): Taxonomy, biostratigraphy, facies and palaeobiogeography. Palaeontologische Zeitschrift 84 (3): 323-344.

Aretz, M. 2011. Corals from the Carboniferous of the Central Sahara (Algeria): The collection "Marie Legrand-blain". Geodiversitas 33 (4): 581624.
Aretz, M., J. Denayer, and B. Mottequin. 2013. Preliminary data on Visean (Carboniferous) corals and brachiopods from the strata between Djebel Begaa and the Gara el Itima (eastern Tafilalt, Morocco). International field symposium "the Devonian and lower Carboniferous of northern Gondwana", 87-94.

Aretz, M., and H.G. Herbig. 2010. Corals from the Visean of the central and southern part of Azrou-Khénifra Basin (Carboniferous, central Moroccan Meseta) X coral symposium St Petersburg. Palaeoworld 19 (3-4): 295-304.

Bamber, E.W., and W.J. Sando. 1985. Coral zonation of the Mississippian system in the Western Interior Province of North America. Geological Survey Professional Paper 1334: 1-61.

Beauchamp, J., and A. Izart. 1987. Early Carboniferous basins of the atlasMeseta domain (Morocco): Sedimentary model and geodynamic evolution. Geology 15 (9): 797-800.

Belka, Z. 1985. Lower Carboniferous conodont biostratigraphy in the northeastern part of the Moravia-Silesia Basin. Acta Geologica Polonica $35(1-2): 3-60$.

Belka, Z., and E. Groessens. 1986. Conodont succession across the Tournaisian-Visean boundary beds at Salet, Belgium. Bulletin de la Société belge de Géologie 95 (4): 257-280.

Bischoff, G. 1958. Die Conodonten-Stratigraphie des rheno-herzynischen Unterkarbons mit Berucksichtigung der Wocklumeria-Stufe und der Devon/Karbon-Grenze. Abhandlungen des Hessischen Landesantes für Bodenforschung 19: 1-64.

Boland, K. 1997. Caninoid Rugose corals of the lower Tournaisian (Hastarian) of Belgium: Systematics and evolution. Boletín de la Real Sociedad Española de Historia Natural. Sección Geológica 91 (1-4): 73-84.

Bouabdelli, M. 1989. Tectonique et sedimentation dans un bassin orogenique: le sillon viséen d'Azrou-Khenifra (Est du Massif hercynien central du Maroc). In Thése Doctorat ès Sciences, 269. Strasbourg: Université Louis Pasteur.

Branson, E.B., and M.G. Mehl. 1934. Conodonts from the Bushberg sandstone and equivalent formations of Missouri. Columbia, University of Missouri Studies 8 (4): 265-299.

Branson, E.B., M.G. Mehl. 1938. Conodonts from the lower Mississippian of Missouri, In E.B. Branson, M.G. Mehl, A.K. Miller, R. Peck, I.A. Keyte, W.M. Furnish, Stratigraphy and paleontology of the lower Missisippian of Missouri, Part 2: Columbia, University of Missouri Studies 13 (4): 28-148.

Chanton-Güvenç, N., P. Huvelin, and P. Semenoff-Tian-Chansky. 1971. Les deux series d'âge viséen supérieur du Jbel Hadid près de Khénifra (Maroc hercynien central). Notes et Mémoires du Service géologique du Maroc 31: 7-10.

Conil, R., E. Groessens, M. Laloux, E. Poty, and F. Tourneur. 1990. Carboniferous guide foraminifera, corals and conodonts in the FrancoBelgian and Campine basin and their potential for widespread correlation. Courier Forschungsinstitut Senckenberg 130: 15-30.

De Fromentel, E. 1861. Introduction à l'étude des éponges fossiles. Société Linnéene de Normandie, Mémoires. Vol. 11, 150.

Degtiarev, D.D. 1972. Osnovnye etapy istoricheskogo razvitifa kamennougol'nykh korallov na Urale. Fauna i biostratigrafiya srednego verkhnego paleozoia Urala. Sverdlovsk Gornyi Instituta Trudy 93: 79-92.

Denayer, J. 2015. Rugose corals at the Tournaisian-Visean transition in the central Taurides (S Turkey) - Palaeobiogeography and palaeoceanography of the Gondwana margin. Journal of Asian Earth Sciences 98: 371-398.

Denayer, J., E. Poty, and M. Aretz. 2011. Uppermost Devonian and Dinantian rugose corals from southern Belgium and surrounding areas. In Field guides $11^{\text {th }}$ international symposium on fossil Cnidaria and Porifera, Liège 2011. Kolner Forum von Geologie und Paleontologie, ed. M. Aretz and E. Poty, vol. 20, 151-201.

Devuyst, F.-X., L. Hance, H.F. Hou, X.H. Wu, S.G. Tian, M. Coen, and G. Sevastopulo. 2003. A proposed global Stratotype section and point for the base of the Visean stage (Carboniferous): The Pengchong section, Guangxi, South China. Episodes 26: 105-115.

Devuyst, F.-X., and J. Kalvoda. 2007. Early evolution of the genus Eoparastaffella (foraminifera) in Eurasia: The "interecta group" and related forms, late Tournaisian to early Visean (Mississippian). Journal of Foraminiferal Research 37: 69-89.

Dixon, O.A. 1970. Variation in the Visean coral Caninia benburbensis from north-West Ireland. Palaeontology 13 (1): 52-63. 
Dobrolyubova, T.A., N.B. Kabakovich, and T.A. Sayutina. 1966. Lower Carboniferous corals of the Kuznets Basin. Trudy Paleontologicheskogo Instituta 111: 1-276.

Dybowski, W.N. 1873. Monographie der Zoantheria, Sclerodermata Rugosa aus der Silurformation Estlands, Nord-Livlands und der Insel Gotland. Archiv für die Naturkunde Liv-, Est- und Kurlands Serie 1 (5): 257-414.

Ehrenberg, C.G. 1834. Beiträge zur physiologischen Kenntniss der Corallenthiere im allgemeinen, und besonders des rothen Meeres, nebst einem Versuche zur physiologischen Systematik derselben. Abhandlungen der Könichlicher Akademie der Wissenschaften 1932: 225-380.

Falces, S., and S. Rodríguez. 2002. Occurrence of reworked specimens of the rugose coral genus Sychnoelasma in the Guadiato valley (Serpukhovian, SW Spain). Coral Research Bulletin 7: 47-52.

Fedorowski, J. 1981. Carboniferous corals: Distribution and sequence. Acta Palaeontologica Polonica 26 (2): 87-160.

Fontaine, H. 1980. Sychnoelasma urbanowitschi Stuckenberg, espece corallienne du Carbonifère de Normandie, de la Sarthe et du Morvan. Bulletin de la Societé d'Histoire Naturelle et des Amis du Muséum d'Autun 95: 19-26.

Frey, H., and G.G.F.R. Leuckart. 1847. Beiträge zur Kenntniss wirbelloser Thiere mit besonderer Berücksichtigung der Fauna des Norddeutschen Meeres, 170.

Garwood, E.J. 1916. The faunal succession in the lower Carboniferous rocks of Westmoreland and North Lancashire. Proceedings of the Geologists' Association 27: 1-43.

Gigout, M. 1951. Etudes géologiques sur la Meseta marocaine occidentale. Notes et Mémoires du Service géologique du Maroc 86: 1-506.

Groessens, E. 1975. Preliminary range chart of conodont biozonation in the Belgian Dinantian. In International Symposium on Belgian Micropaleontological Limits from Emsian to Visean, Namur, ed. J. Bouckaert and M. Streel, vol. 17, 1-193. Brussels: Geological Survey of Belgium (imprinted 1974).

Hill, D. 1938. A Monograph on the Carboniferous Rugose Corals of Scotland. Palaeontological Society of London Monograph, Pt. 1 (1-78), Pt. 2 (79114), Pt. 3 (115-204)

Hill, D. 1981. Rugosa and Tabulata. In Treatise on Invertebrate Paleontology Part F (Supplement 1), ed. C. Teichert, vol. 2, 762. Boulder and Lawrence: Geological Society of America and University of Kansas Press.

Hoepffner, Ch., A. Soulaimani, and A. Piqué. 2005. The Moroccan Hercynides. Journal of African Earth Sciences 43: 144-165.

Howell, E.J. 1938. Rugose corals from mid-Avonian Limestones of West Glamorgan. Annals and Magazine of Natural History 11 (1): 1-22.

Hubbard, J.A. 1970. Sedimentological factors affecting to growth of Visean caninoid corals in Northwest Ireland. Palaeontology 13 (2): 191-209.

Hudson, R.G. 1928. On the lower Carboniferous corals Cravenia rhytoides and Cravenia tela, gen. Et spp. nov. Proceedings of the Leeds Philosophical and Literary Society, Scientific section 1: 252-257.

Huvelin, P. 1969. Mouvements hercyniens precoces et structure du Jebel Hadid près de Khenifra (Maroc). Comptes Rendus Académie Science, Paris, Serie D 269: 2305-2308.

Huvelin, P., and B. Mamet. 1997. Transgressions, faulting and redeposition phenomenon during the Visean in the Khenifra area, western Moroccan Meseta. Journal of African Earth Sciences 25 (3): 393-399.

Izart, A., E. Poty, and J.L. Vieslet. 1989. Le Viséen de la boutonière de Skoura (Haut Atlas, Maroc). Notes et Mémoires du Service géologique du Maroc 335: 67-75.

Jia, H., and S. Xu. 1977. Rugosa and Tabulata. Paleontological Atlas of Central South China 2: 109-272 (in Chinese).

Lafuste, J. 1983. Passage des microlamelles aux fibres dans la muraille d'un Tabulé "Michelinomorphe" du Viséen du Sahara Algérien. Geobios 16 (6): 755-758.

Lafuste, J.G., and Y. Plusquellec. 1985. Structure et microstructure de quelques Micheliniidae et Michelinimorphes (Tabulata paléozoïques). Bulletin du Museum National d'Histoire Naturelle. Section C. Sciences de la Terre, Paléontologie, Géologie, Minéralogie 7: 13-63.

Lang, W.D., S. Smith, and H.D. Thomas. 1940. Index of Palaeozoic Coral Genera, 231. London: British Museum (Natural History).

Lecointre, G. 1926. Recherches géologiques dans la Meseta marocaine. Mémoires du Sociéte des Sciences naturelles du Maroc 14: 1-158.

Leleshus, V.L. 1991. Ein letzter Vertreter der Thecostegidae (Tabulata) aus dem Mittelkarbon von Darwas (Tadzhikische SSR). Paläontologiches Zeitschrift 65: 71-75.
Lewis, H.P. 1927. Caninia cylindrica Scouler and other large Caninia from the Carboniferous limestone of Ireland. Scientific Proceedings of the Royal Society of Dublin 18 (30): 373-382.

Mamet, B.L. 1974. Une zonation par foraminiferes du Carbonifere inferieur de la Tethys occidentale. In Comptes Rendus du $7 m e$ Congres International de Stratigraphie et de Geologie du Carbonifere, Krefeld 1971, vol. 3, 391-408.

Matley, C.A., and A. Vaughan. 1906. The Carboniferous rocks at Rush (county Dublin). Quarterly Journal of the Geological Society 62: 275-323.

McCoy, F. 1844. A synopsis of the characters of the Carboniferous limestone fossils of Ireland, 1-207. Dublin: University Press.

Michard, A., A. Soulaimani, C. Hoepffner, H. Ouanaimi, L. Baidder, E.C. Rjimati, and O. Saddiqi. 2010. The south-western branch of the Variscan Belt: Evidence from Morocco. Tectonophysics 492: 1-24.

Michelin, H. 1843. Iconographie zoophytologique, description par localites et terrains des polypiers fossiles de France et pays environnants, 348. Paris.

Milne-Edwards, H, J. Haime. 1850-1855. A Monograph of the British fossil corals. 1850 (p. 1-71), 1852 (p. 147-210), 1853 (p. 211-244), 1855 (p. 245-299). Palaeontographical society, London.

Mitchell, M. 1973. The base of the Visean in south-west and north-West England. Proceedings of the Yorkshire Geological Society 39: 151-160.

Mitchell, M. 1989. Biostratigraphy of Visean (Dinantian) Rugose coral faunas of Britain isles. Proceedings of the Yorkshire Geological Society 47 (3): 233-247.

Mitchell, M., and I.D. Somerville. 1988. A new species of Sychnoelasma (Rugosa) from the Dinantian of the British Isles: Its phylogeny and biostratigraphical significance. Proceedings of the Yorkshire Geological Society 47 (2): 155-162.

Ogar, V. 2006. Corals at the Tournaisian-Visean boundary, the middle Tien-Shan. In Paleontological and biostratigraphic problems of the Proterozoic and Phanerozoic of Ukraine, ed. P.F. Gozhik, 58-65. Institute Heolohičnych Kyiv.

Ogar, V., M. Falahatgar, and M. Mosaddegh. 2013. Visean corals of the Kiyasar area (north of Iran). Revista Brasileira de Paleontologia 16 (3): 375-396.

Phillips, J. 1836. Illustrations of the geology of Yorkshire, part 2: The mountain Limestone District, 1-253. London: John Murray.

Poty, E. 1981. Recherches sur les Tétracoralliaires et les Hétérocoralliaires du Viséen de la Belgique. Mededelingen Rijks Geologische Dienst 35-1: 1-161.

Poty, E. 1983. Distribution stratigraphique des tetracoralliaires et heterocoralliaires dans Le Viseen de la Belgique. Annales de la Société Géologique de Belgique 106: 57-68.

Poty, E. 1985. A rugose coral biozonation from the Dinantian of Belgium as a basis for a coral biozonation of the dinantian of Eurasia. Compte Rendu X International Carboniferous Congress, IGME, Madrid 1: 29-31.

Poty, E. 1989. Distribution and palaeogeographic affinities of Belgian Tournaisian rugose corals. Memoirs of the Association of Australasian Palaeontologists 8: 267-273.

Poty, E., and K. Boland. 1996. Revision des tetracoralliaires caninomorphes de l'Hastarien (Tournaisien) belge. Annales de la Société Géologique de Belgique 117 (1): 201-225.

Poty, E., F.-X. Devuyst, and L. Hance. 2006. Upper Devonian and Mississippian foraminiferal and rugose coral zonations of Belgium and northern France: A tool for Eurasian correlations. Geological Magazine 143: 829-857.

Poty, E., and D. Hannay. 1994. Stratigraphy of rugose corals in the Dinantian of the Boulonnais (France). Mémoires de I'Institut géologique de I'Université de Louvain 35: 51-82.

Rhodes, F.H.T., R.L. Austin, and E.C. Druce. 1969. British Avonian (Carboniferous) conodont faunas, and their value in local and intercontinental correlation. Bulletin of the British Museum (Natural History). Geology Supplement 5: 1-313.

Rodríguez, S. 1984. Corales rugosos del Este de Asturias. Ed. Complutense 109 (84): $1-529$.

Rodríguez, S., I. Said, I.D. Somerville, P. Cozar, and I. Coronado. 2016a. Serpukhovian coral assemblages from Idmarrach and Tirhela formations (Adarouch, Morocco). Geologica Belgica 19 (1-2): 29-42.

Rodríguez, S., and I.D. Somerville. 2007. Comparisons of rugose corals from the upper Visean of SW Spain and Ireland: Implications for improved resolutions in late Mississippian coral biostratigraphy. In Fossil Corals and Sponges. Proceedings of the $9^{\text {th }}$ international symposium on fossil Cnidaria and Porifera, Graz, 2003. Austrian Academy of Sciences, 
Schriftenreihe der Erdwissenschaftlichen Kommissionen, ed. B. Hubmann and W.E. Piller, vol. 17, 275-305.

Rodríguez, S., I.D. Somerville, P. Cozar, I. Coronado, and I. Said. 2016b. Inventory and analysis of the distribution of Visean corals from the Guadiato area, SW Spain. Spanish Journal of Palaeontology 31 (1): 181-220.

Rodríguez, S., I.D. Somerville, I. Said, and P. Cózar. 2012. Late Visean coral fringing reef at Tiouinine (Morocco): Implications for the role of rugose corals as building organisms in the Mississippian. Geological Journal 47: 462-476.

Rodríguez, S., I.D. Somerville, I. Said, and P. Cózar. 2013. An upper Visean (Asbian-Brigantian) and Serpukhovian coral succession at Djebel Ouarkziz (northern Tindouf Basin, southern Morocco). Rivista Italiana di Paleontologia e Stratigrafia 119 (1): 3-17.

Said, I. 2005. Estudio de los corales rugosos con disepimentos del Mississippiense del NE de la Meseta marroquí (sectores de Adarouch y Agouaraii). Ph.D. Thesis, Universidad Complutense de Madrid, 1-240.

Said, I., M. Berkhli, and S. Rodríguez. 2007. Preliminary data on the coral distribution in the upper Visean (Mississippian) succession from Adarouch area (NE Central Morocco). In Fossil Corals and Sponges. Proceedings of the $9^{\text {th }}$ international symposium on fossil Cnidaria and Porifera. Schriftenreihe der Erdwissenschaftlichen Kommission, ed. B. Hubmann and W. Piller, vol. 17, 353-364.

Said, I., I.D. Somerville, S. Rodríguez, and P. Cózar. 2013. Mississippian coral assemblages from the Khenifra area, Central Morocco: Biostratigraphy, biofacies, palaeoecology and palaeobiogeography. Gondwana Research 23: $367-379$

Salée, A. 1913. Formes nouvelles du genre "Caninia". Bulletin de la Société Belge de Géologie 26: 41-49.

Sando, W.J. 1990. Global Mississippian coral zonation. Courier Forschung Institut Senckenberg 130: 173-187.

Sando, W.J., and E.W. Bamber. 1985. Coral zonation of the Mississippian system in the Western Interior Province of North America. Geological Survey Professional Paper 1334: 1-61.

Sayutina, T.A. 1976. On the genus Sychnoelasma in the lower Carboniferous deposits of the northern Urals [rode Sychnoelasma iz Niznekamennougolnij otlozhenii severnogo Urala]. Bulletin of the Moscow Society of Naturalist. Geological Series 51 (1): 111-123 (in Russian).

Schindewolf, O.H. 1938. Zur Kenntniss der Gattung Zaphrentis (Anthozoa, Tetrakorallia) und er sogennanten Zaphrentiden des Karbons. Jahrbuch der Preussische geologische Landesanstalt 58: 439-454.

Schouppé, A.V., and P. Stacul. 1955. Die genera Verbeekiellia Penecke, Timorphyllum Gerth, Wannerophyllum n.gen., Lophophyllidium Grabau us dem perm von Timor. Palaeontographica Supplementbände 4, pt. 5 (3): 95-196.

Semenoff-Tian-Chansky, P. 1974. Recherches sur les Tetracoralliaires du Carbonifere du sahara Occidental. Editions du Centre Nationale de la Recherche Scientifique, Ser. 6, Science de la Terre 30: 1-316. Paris.

Semenoff-Tian-Chansky, P. 1985. Corals. In The Carboniferous of the World, II, Australia, Indian subcontinent, South Africa, South America and North Africa, ed. R.H. Wagner, C.F. Winkler-Prins, and L.F. Granados, vol. 20, 374-381. IUGS Publication.

Sibly, T.F. 1906. On the Carboniferous limestone (Avonian) of the Mendip area (Somerset), with special reference to the palaeontological sequence. Quarterly Journal of the Geological Society 62: 324-380.

Smyth, L.B. 1925. A contribution to the geology of Great Ome's head. Science Proceedings of the Royal Society of Dublin 18: 141-164.

Sokolov, B.S. 1947. Novye Tabukata ordovika Grenlandii (new Ordovician Tabulata from Greenland). AkademiyaNauk SSSR Doklady 58 (3): 469-472 (in Russian).

Somerville, I.D. 1994. Early Carboniferous rugose coral assemblages from the Dublin Basin, Ireland: Possible bathymetric and palaeoecologic indicators. Courier Forschung Institut Senckenberg 172: 223-229.

Somerville, I.D. 1997. Rugose coral faunas from upper Visean (AsbianBrigantian) buildups and adjacent platform limestones, Kingscourt, Ireland. Boletín de la Real Sociedad Española de Historia Natural. Sección Geológica 92 (1-4): 35-47.
Somerville, I.D. 2008. Biostratigraphic zonation and correlation of Mississippian rocks in Western Europe: Some case studies in the late Visean/Serpukhovian. Geological Journal 43: 209-240.

Somerville, I.D., P. Cózar, I. Said, D. Vachard, P. Medina-Varea, and S. Rodríguez. 2013. Palaeobiogeographic constraints on the distribution of foraminifers and rugose corals in the Carboniferous Tindouf Basin, S. Morocco. Journal of Palaeogeography 2: 1-18.

Somerville, I.D., M. Mitchell, and A.R.E. Strank. 1986. An Arundian fauna from the Dyserth area, North Wales and its correlation within the British Isles. Proceedings of the Yorkshire Geological Society 46 (1): 57-75.

Somerville, I.D., S. Rodríguez, and I. Said. 2016. Carboniferous aulate corals from. Azrou-Khenifra Basin (Morocco): distribution and phylogenetic relationships Geobios 49 (4): 303-317.

Somerville, I.D., S. Rodríguez, I. Said, and P. Cózar. 2012. Mississippian coral assemblages from Tabainout mud-mound complex, Khenifra area Central Morocco. Geologica Belgica 15 (4): 308-316.

Stuckenberg, A.A. 1895. Koralli i mshanki kamennougolnij otlodzhenii Urala i Timana. Trudy Geologicheski Komite 3: 3-178 (in Russian).

Tyson, R.V. 1993. Palynofacies analysis. In Applied Micropalaeontology, ed. D.J. Jenkins, 153-191. Dordrecht: Kluwer.

Tyson, R.V. 1995. Sedimentary organic matter: Organic Facies and Palynofacies. London: Chapman and Hall.

Tchudinova, I.I. 1970. New Tabulata from the Paleozoic of Transcaucasia. In New species of Paleozoic bryozoans and corals, 97-111. Moscow: Nauka (in Russian).

Tchudinova, I.I. 1986. Sostav sistema i filogeniya iskopaemij korallov. Otriad siringoporida. Trudy Paleontologicheski Institut 216: 1-204.

Termier, G., and H. Termier. 1950. Paleontologie marocaine II. Invertebres de l'Ere Primaire. Foraminiferes, spongoaires et coelenteres. Notes et Mémoires du Service géologique du Maroc 73: 1-220.

Termier, H. 1936. Études géologiques sur le Maroc central et le Moyen-Atlas meridional; t. 1: Les terrains primaires et le Permo-Trias. Notes et Mémoires du Service de Mines Carte géologique Maroc 33: 1-743.

Thompson, T.L., and L.D. Fellows. 1970. Stratigraphy and conodont biostratigraphy of Kinderhookian and Osagean (lower Mississippian) rocks of southwestern Missouri and adjacent areas. Vol. 45, 1-263. Rolla: Missouri Geological Survey and Water Resources, Report of Investigations.

Tourneur, F., R. Conil, and E. Poty. 1989. Donnees preliminaires sur les tabules et les chaetetides du Dinantien de la Belgique. Bulletin de la Société belge de Géologie 98: 401-442.

Varker, W.J., and G.D. Sevastopulo. 1985. The Carboniferous system: Part 1 Conodonts of the Dinantian subsystem from Great Britain and Ireland. In A stratigraphical index of conodonts, ed. A.C. Higgins and R.L. Austin, 167-209. Chichester: The British Micropalaeontological Society.

Vassiljuk, N.P. 1960. Lower Carboniferous corals of the Donets Basin. Trudy Acadamie Science Ukraine, SSR, Stratigraphy, Paleontology 13: 1-181 (In Paris).

Vaughan, A. 1905. The paleontological sequence in the Carboniferous limestone of the Bristol area. Quarterly Journal of the Geological Society 61: 181-307.

Verrill, A.E. 1865. Classification of polyps (extract condensed from a synopsis of the polypi of the North Pacific exploring expedition, under captains Ringgold and Rodgers, U.S.N.). Essex Institute Proceedings 4: 145-149.

Von Bitter, P.H., C.A. Sandberg, and M.J. Orchard. 1986. Phylogeny, speciation, and palaeoecology of the early Carboniferous (Mississippian) conodont genus Mestognathus. Royal Ontario Museum, Life Sciences Contributions 143: 1-115.

Vuillemin, C. 1990. Les Tétracoralliaires (rugosa) du Carbonifère Inférieur du Massif Armoricain (France). In Cahiers de Paléontologie, Éditions du CNRS, Paris, 1-171.

Waagen, W.H., and J. Wentzel. 1886. Salt range fossils, v. 1, Productus limestone fossils; 6, Coelenterata. Paleontologica Indica, Series 13: 835-924.

Wang, H.C. 1950. A revision of the Zoantheria Rugosa in the light of their minute skeletal structures. Philosophical Transactions of the Royal Society of London, Section B 234: 175-246. 
Wang, X.D., S.Z. Shen, T. Sugiyama, and R.R. West. 2003. Late Palaeozoic corals of Tibet (Xizang) and West Yunnan, Southwest China: Successions and palaeobiogeography. Palaeogeography, Palaeodlimatology, Palaeoecology 191: 385-397.

Webb, G.E. 2002. Latest Devonian and early Carboniferous reefs: Depressed reef building after the middle Paleozoic collapse. In Phanerozoic Reef Patterns, ed. W. Kiessling, E. Flügel, and J. Golonka, vol. 72. Oklahoma: SEPM Society for Sedimentary Geology.

Wedekind, R. 1937. Einfuhrung in die Grundlagen der historischen Geologie, H. Band Mikrobiostratigraphie. Die Korallen und Foraminferenzeit, 1-136. Stuttgart: Ferdinand Enke.

Weyer, D. 1993. Korallen aus dem Obertournai und Untervise der Inseln Hiddensee und Rugen. Abhandlungen und Berichte fur Naturkunde 16: $31-69$

Weyer, D. 2000. Korallen im Unterkarbon Deutschlands. Abhandlungen und Berichte fur Naturkunde 23: 57-91.

Wilmore, A. 1910. On the Carboniferous limestone south of the Craven Fault (Grassington-Hellfield District). Quarterly Journal Geological Society London 66: 539-585.

Wood, G.D., A.M. Gabriel, and J.C. Lawson. 1996. Palynological techniques processing and microscopy. Chapter 3. In Palynology: principles and applications, ed. J. Jansonius and D.C. McGregor, vol. 1, 29-50. Dallas: American Association of Stratigraphic Palynologists Foundation.

Ziegler, W. 1960. Die Conodonten aus den Gerollen des Zechsteinconglomerate von Rossensay (sudwestlich Rheinberg/Niederrhein). Fortschritte in der Geologie von Rheinland and Westfalen 6: 1-15.

\section{Publisher's Note}

Springer Nature remains neutral with regard to jurisdictional claims in published maps and institutional affiliations.

\section{Submit your manuscript to a SpringerOpen ${ }^{\circ}$ journal and benefit from:}

- Convenient online submission

- Rigorous peer review

- Open access: articles freely available online

- High visibility within the field

Retaining the copyright to your article

Submit your next manuscript at $\boldsymbol{\nabla}$ springeropen.com 